\title{
Reaction Textures and Metamorphic Evolution of Sapphirine-bearing Granulites from the Gruf Complex, Italian Central Alps
}

\author{
by G.T.R. DROOP AND K. BUCHER-NURMINEN ${ }^{2 * *}$ \\ ${ }^{1}$ Department of Geology and Mineralogy, University of Oxford, Parks Road, \\ Oxford OXI 3PR, England, ${ }^{2}$ Mineralogical Institute, University of Basel, Bernoullistrasse 30. \\ 4056 Basel, Switzerland
}

(Received 30 May 1983; in revised form 29 February 1984)

\begin{abstract}
A B STRACT
Mineral chemistries and textures are described from a suite of sapphirine-bearing granulites from the Gruf Complex of the Italian Central Alps. The granulites contain combinations of garnet, orthopyroxene, sapphirine, sillimanite, cordierite, biotite, quartz, spinel, corundum, staurolite, plagioclase, $\mathrm{K}$-feldspar, ilmenite and rutile, in assemblages with low (usually negative) variance. They are outstanding in that they preserve a textural and chemical record of a protracted metamorphic evolution.

Reaction textures are common and include: (i) pseudomorphs (e.g. of sillimanite after kyanite); (ii) relatively coarse-grained monomineralic reaction rims (e.g. of cordierite between sapphirine and quartz); (iii) fine-grained symplectitic coronas (e.g. of orthopyroxene + sapphirine round garnet); (iv) inclusions, in garnet cores, of minerals (e.g. staurolite) not found elsewhere in the rocks.

Detailed microprobe study has revealed large chemical variations within each phase. Different textural types of each phase have different compositions, and strong zoning is preserved in garnet $(\mathrm{Mg} /(\mathrm{Mg}+\mathrm{Fe})$ from 0.30 to 0.61$)$ and coarse sapphirine. Inclusion populations in garnet correlate with host composition.

The textural and chemical features are interpreted in terms of successive equilibrium assemblages and reactions. Metamorphic conditions operative at each stage in the evolution are calculated using published geothermometers and geobarometers as well as thermodynamically calibrated MAS and FASH equilibria. The results are used to construct a $P-T$-time path for the sapphirine-granulites, which can be summarized as follows:

(i) Increasing $T$ at high $P(>7 \mathrm{~kb})$. Partial melting.

(ii) A maximum $T$ of $\sim 830^{\circ} \mathrm{C}$ attained at $\sim 10 \mathrm{~kb}$.

(iii) Almost isothermal decompression, reaching $750^{\circ} \mathrm{Cat} \sim 5 \mathrm{~kb}$, under conditions of low $\mu_{\mathrm{H}_{2} \mathrm{O}}$.

(iv) Further cooling, and decompression. Localized hydration. Rocks exposed.

The $P$ - $T$-time path is interpreted as the product of a single metamorphic cycle (the tertiary 'Lepontine' event) and is extrapolated to the Gruf Complex as a whole. When combined with published geochronological data, the results indicate an average uplift rate in excess of $2 \mathrm{~mm} / \mathrm{yr}$ for the Gruf Complex between 38 and $30 \mathrm{Ma}$ ago.

An in situ partial melting origin for the sapphirine-granulites is favoured. Extraction of an iron-rich granitic liquid from a normal pelitic palaeosome could generate a refractory residue with the required $\mathrm{Mg}, \mathrm{Al}$-rich composition. The change in bulk solid composition during partial melting is thought to account for the extraordinarily strong zoning in the garnets.
\end{abstract}

\section{INTRODUCTION}

Rocks which preserve a record of an extended metamorphic evolution are the exception rather than the rule. Outstanding examples of such rocks are found among the

* Present address: Department of Geology, University of Manchester, Oxford Road, Manchester, M13 9PL, England.

** Institutt for Geologi, Universitetet i Oslo, Postboks 1047, Blindern, 0316 Oslo, Norway. 


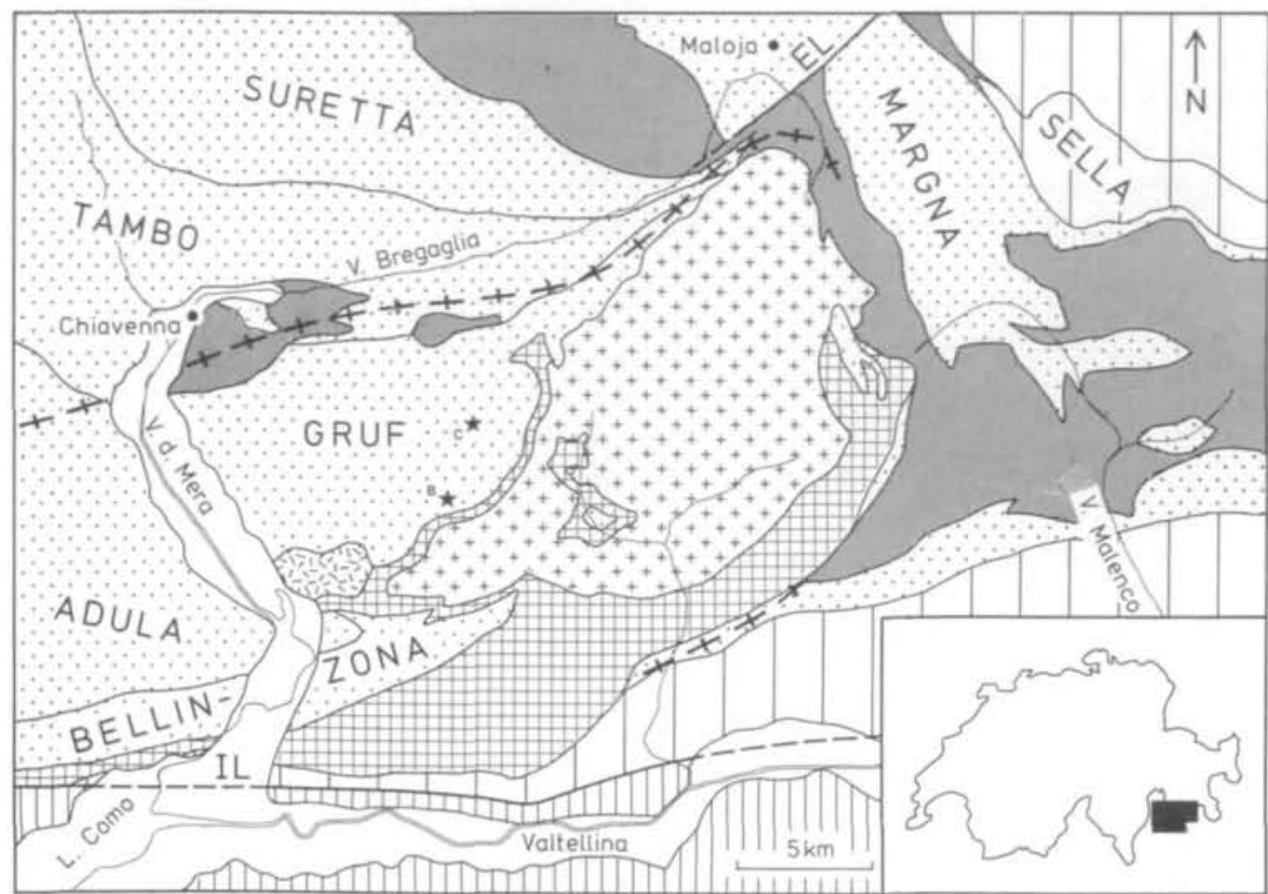

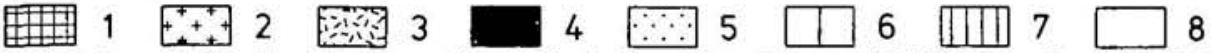

Fig. 1. Sketch-map of the Bergell area, northern Italy (adapted from Trümpy, 1980). 1. Bergell tonalite. 2. Bergell granodiorite. 3. Novate granite. 4. Ultramafics, metavolcanics etc. of ophiolite zones. 5. Pennine nappes (names in capital letters). 6. Austroalpine nappes. 7. Southern Alps. 8. Quaternary. EL. Engadine Line. IL. Insubric Line. + Sillimanite isograd. "Sapphirine locality. (B: Bresciadega locality; C: Val Conco locality.) Inset: location of map area relative to Switzerland.

sapphirine-bearing aluminous magnesian granulites from the Gruf Complex of the Italian Central Alps. This paper is an attempt to extract historical information from mineral textures and chemistry with the aim of providing constraints on the tectono-thermal evolution of the Gruf Complex.

The Gruf Complex is a high grade gneiss unit of the Pennine Zone situated entirely within the Lepontine sillimanite zone (Fig. 1). The Gruf Complex underlies the Bergell Granite Complex; its tectonic position in the sequence of the Pennine nappes is uncertain, though it probably correlates with the Zone of Bellinzona (Wenk, 1973). It is composed mainly of migmatitic biotite-feldspathic gneisses and cordierite-bearing pelitic gneisses (Wenk et al., 1974; Bucher-Nurminen \& Droop, 1983), but ultramafic and calc-silicate rocks occur locally (Moticska, 1970). Hercynian $\mathrm{Rb} / \mathrm{Sr}$ whole-rock ages have been obtained from some of the migmatitic gneisses (Gulson, 1973).

The Gruf sapphirine-granulites contain garnet, orthopyroxene, sillimanite, sapphirine, cordierite, biotite, quartz, spinel, corundum, staurolite, plagioclase, K-feldspar, ilmenite and rutile. They were discovered by Cornelius (1916) as rare blocks in a single fossil scree fan 1.3 $\mathrm{km}$ east of Bresciadega in Val Codera (Fig. 1). Recent scree deposits nearby contain no sapphirine-granulite boulders, suggesting that the outcrops are small, if not already totally eroded away. Wenk et al. (1974) report one boulder of sapphirine-bearing rock at a second locality in Val Codera (southern end of Val Conco; Fig. 1). No sapphirine-granulites have been found in situ.

Although many workers have studied the Gruf sapphirine-granulites, there is still no consensus regarding the origin of their unusual $\mathrm{Mg}, \mathrm{Al}$-rich bulk compositions or their 
metamorphic history. Some textural and mineralogical aspects were discussed by Cornelius \& Dittler (1929) who concluded that the rocks had had a complex history and postulated metasomatic action of pegmatitic fluids from the nearby Bergell intrusion on a biotite-rock protolith to account for the present bulk compositions. Barker (1964) identified four successive mineral assemblages on the basis of textural evidence. Ackermand \& Seifert (1969) invoked a two-stage metamorphic history and calculated a pressure of $12 \mathrm{~kb}$ for the earlier ('pre-intrusive granulite facies') stage, though no indication was given of the methods used. In his field study of the Gruf Complex, Moticska (1970) briefly described the sapphirinegranulites and stressed that they contain disequilibrium mineral assemblages. Wenk et al. (1974), in discussing the cordierite-bearing metapelites of the Bergell region, calculated conditions of $1000^{\circ} \mathrm{C}$ and $8 \mathrm{~kb}$ for the sapphirine-granulites assuming the mineral assemblage had equilibrated in a single-stage metamorphism. Recently, Hoernes \& Friedrichsen (1980) have obtained concordant oxygen isotope temperatures of between 658 and $686^{\circ} \mathrm{C}$ from minerals separated from one specimen.

Our samples revealed a large number of mineral textures not recorded by previous workers. These textures confirm earlier observations that the rocks had a complicated metamorphic history and suggest that present mineral assemblages were never in chemical equilibrium on the scale of a thin-section. This is borne out by the low variance of these assemblages ( -3 in some samples). In this paper we describe these textures in detail and use them to trace the evolution of the rocks in terms of successive equilibrium mineral assemblages and reactions; we then attempt to calculate the pressure and temperature conditions operative at each stage.

\section{PETROGRAPHY}

\section{Macroscopic features}

The three petrographic varieties of sapphirine-bearing rock are as follows:

(a) Granulites (samples AL18, AL20, AL21, TS100, Cod12). This is the most common type at the Bresciadega locality. These rocks are dense, coarse-grained, non-foliated, and dark-coloured due to a high modal proportion of ferro-magnesian silicates ( $>90$ per cent). Large $(>2 \mathrm{~cm}$ ) irregular to sub-rounded garnet porphyroblasts are set in a matrix (grain size 1-3 mm) in which sapphirine, orthopyroxene, cordierite, biotite and $\mathrm{K}$-feldspar are clearly distinguishable. In some samples, $\mathrm{K}$-feldspar is concentrated in irregular monomineralic patches.

(b) Schist (AL41). In this rock (from Bresciadega), biotite is abundant and forms streaks which define a rudimentary schistosity. Garnet is less prominent than in the granulites and 2-4 mm ellipsoidal pale blue patches rich in fine-grained sapphirine are conspicuous.

(c) Mixed rocks (AL19, Cod6A). In this type, dark sapphirine-bearing rock is closely associated with paler quartose rock resembling metapelitic gneiss found in situ. In AL19 (from Bresciadega), half of the rock is composed of 'normal' sapphirine-granulite ((a) above); this is separated from pale foliated garnetiferous quartzo-feldspathic gneiss by a sharp and concordant planar contact. There is a more intimate association of dark and light material in Cod6A (the Val Conco boulder reported by Wenk et al. (1974)), in which randomly distributed dark lensoid fragments (up to $20 \mathrm{~cm}$ long) rich in garnet, biotite and fine grained sapphirine are set in a matrix of medium coarse-grained quartzo-feldspathic rock containing garnet and biotite.

The Bresciadega samples may well have been derived from a single lens-like body similar to, but much larger than, those in Cod6A. If so AL19 may be a sample across the margin of the lens. 


\section{Microscopic features}

The mineral assemblages of rocks studied in this paper are listed in Table 1.

\section{(a) Granulites}

Most samples have a modal compositionclose to: orthopyroxene, 25 per cent; sapphirine, 20 per cent; cordierite, 20 per cent; biotite, 15 per cent; garnet, 8 per cent; feldspars, 5 per cent; quartz, 3 per cent; sillimanite, 2 per cent; spinel, corundum and other accessories, 2 per cent.

Garnet. Garnet diameters range from 1 to $20 \mathrm{~mm}$. The larger grains tend to be subrounded, though occasionally have a fragmented atoll-like appearance, while smaller ones have irregular lobate shapes. Crystal faces are absent. Grain boundaries are strongly embayed (Figs. 2, 3) suggesting that garnet has been resorbed. Two other features support this: (i) small ragged 'islands' of garnet up to $3 \mathrm{~mm}$ away from the nearest large grain (Figs. 2, 4c); (ii) the almost ubiquitous $0 \cdot 1-2 \mathrm{~mm}$ wide symplectitic corona around each garnet (Figs. 2, 3, $4 a, 4 b$ ). These coronas are composed predominantly of orthopyroxene + cordierite symplectite (Figs. 3, 4a) similar to those described by Schreyer \& Abraham (1978), Leyreloup et al. (1975) and Vielzeuf (1980) from coronas around garnet in other pelitic granulites. Locally, the coronas contain fan-shaped patches of very finely intergrown orthopyroxene + sapphirine and small amounts of orthopyroxene + spinel symplectite (Fig. $4 b$ ). These two types of intergrowth are also known from textures in the pelitic granulites of Madras (Grew, 1982a).

Sapphirine, orthopyroxene, cordierite, sillimanite, staurolite, biotite, spinel, corundum, quartz, plagioclase, $\mathrm{K}$-feldspar, ilmenite, rutile and apatite have been observed as inclusions in garnet. Of these, staurolite, ilmenite, rutile and apatite are not found elsewhere in the rock. Many of the inclusions are composite, and a list of all recorded inclusion assemblages is given in Table 2. Some of the more common or significant types of composite inclusions are illustrated in Fig. 6.

TABLE 1

Mineral assemblages of Gruf sapphirine-bearing rocks

\begin{tabular}{|c|c|c|c|c|c|c|c|c|c|c|c|c|c|c|c|c|c|c|c|c|}
\hline $\begin{array}{l}\text { Sample } \\
\text { number }\end{array}$ & & 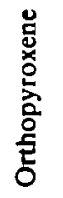 & 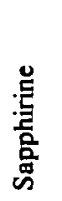 & 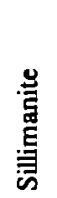 & 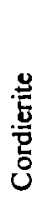 & 点 & 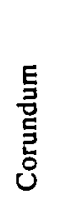 & 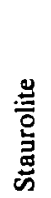 & $\begin{array}{l}\stackrel{u}{0} \\
.0\end{array}$ & 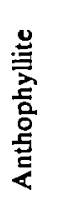 & 莺 & 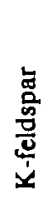 & 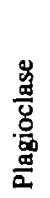 & 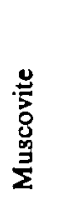 & $\begin{array}{l}\stackrel{0}{E} \\
\frac{0}{\mathcal{L}}\end{array}$ & 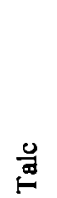 & $\begin{array}{l}\stackrel{\mathscr{U}}{\overline{\mathbf{E}}} \\
\underline{\underline{E}}\end{array}$ & $\frac{0}{a}$ & 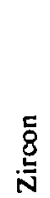 & 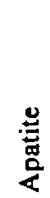 \\
\hline AL18 A & $x$ & $\mathrm{X}^{2}$ & $\mathrm{X}^{2}$ & $\mathrm{x}$ & $\mathrm{x}$ & 0 & & & $\mathrm{x}$ & $\mathrm{X}^{*}$ & $\mathrm{X}$ & & $\mathbf{x}$ & & & & & 0 & 0 & o \\
\hline AL19 r & $\mathrm{x}$ & $\mathrm{X}^{2}$ & $\mathrm{X}^{2}$ & $\mathrm{x}$ & $\mathrm{x}$ & 0 & $\mathrm{O}^{1}$ & & $\mathrm{x}$ & & $\mathrm{x}$ & & $\mathbf{x}$ & & & & & & o & \\
\hline AL19 leu. & $\mathrm{x}$ & & & $\mathbf{x}$ & $\mathrm{x}$ & 0 & & & 0 & & $\mathrm{x}$ & $\mathrm{x}$ & $\mathbf{x}$ & $\mathrm{O}^{*}$ & & & 0 & $\mathrm{O}$ & 0 & \\
\hline AL20A & $\mathrm{x}$ & $\mathrm{X}^{2}$ & $\mathrm{X}^{2}$ & $x$ & $\mathrm{x}$ & 0 & & & $\mathrm{X}$ & & $\mathrm{x}$ & $\mathrm{x}$ & & & & & $\mathrm{O}^{\prime}$ & $\mathrm{O}^{1}$ & 0 & \\
\hline AL20B & $\mathrm{x}$ & $\mathrm{X}^{2}$ & $\mathrm{X}^{2}$ & $\mathbf{X}^{\prime}$ & $\mathrm{x}$ & $\mathrm{X}^{\mathrm{c}}$ & $x^{c}$ & $\mathrm{O}^{\prime}$ & $\mathrm{X}$ & & $\mathrm{x}$ & $\mathrm{x}$ & $\mathrm{x}$ & & & & $\mathrm{O}^{\prime}$ & $\mathrm{O}^{\prime}$ & 0 & o \\
\hline AL21 & $\mathrm{x}$ & $\mathrm{X}^{2}$ & $x$ & $X^{\prime}$ & $\mathrm{x}$ & $X^{\prime}$ & & & $\mathrm{x}$ & & & $\mathrm{X}$ & $\mathrm{x}$ & & & & $\mathrm{O}^{\prime}$ & $\mathrm{O}^{\prime}$ & 0 & \\
\hline AL41 & $\mathrm{x}$ & $\mathrm{P}^{2}$ & $\mathrm{x}^{2}$ & $\mathrm{x}$ & $\mathrm{x}$ & $X^{\prime}$ & & $O^{1}$ & $\mathrm{X}$ & $\mathrm{X}^{\prime}$ & & & $\mathrm{x}$ & & $\mathrm{X}^{\prime}$ & $0^{*}$ & $\mathrm{O}^{\prime}$ & $\mathrm{O}^{\prime}$ & & 0 \\
\hline TS 100 & $\mathrm{x}$ & $\mathrm{X}^{2}$ & $\mathrm{X}^{2}$ & $\mathrm{x}$ & $\mathrm{x}$ & $\mathrm{x}$ & & $O^{\prime}$ & $\mathrm{x}$ & & $\mathrm{x}$ & $\mathbf{x}$ & $\mathrm{x}$ & $\mathrm{O}^{2}$ & & & $\mathrm{O}^{\prime}$ & $\mathrm{O}^{1}$ & 0 & $\mathbf{O}^{\prime}$ \\
\hline Cod6A mel. & $\mathrm{x}$ & & $\mathrm{x}$ & & & $\mathrm{x}$ & 0 & & $\mathrm{x}$ & & & & $\mathrm{x}$ & & & & & & 0 & \\
\hline Cod6A leu. & $\mathrm{X}$ & $\mathbf{X}$ & & & & & & & $\mathbf{x}$ & & $\mathrm{x}$ & $\mathbf{x}$ & $\mathrm{X}$ & & $\mathrm{O}^{*}$ & & 0 & & o & o \\
\hline Cod12 & $\mathrm{X}$ & $\mathrm{X}$ & $\mathrm{x}$ & 0 & $\mathrm{x}$ & $\mathrm{O}$ & 0 & & $\mathrm{x}$ & & $\mathrm{X}$ & $\mathrm{X}$ & $\mathrm{x}$ & & & & & & & \\
\hline
\end{tabular}

$\mathrm{X}$ : Essential mineral.

$O$ : Accessory mineral.

P: Former existence inferred from pseudomorphs.

a: Only as a retrogressive alteration product.

c: Only as inclusions in garnet and prismatic sapphirine. $\mathrm{i}$ : Only as inclusions in garnet. $\mathrm{s}$ : Only in symplectite. leu: Leucosome. mel: Melanosome. 2: At least 2 generations present. 


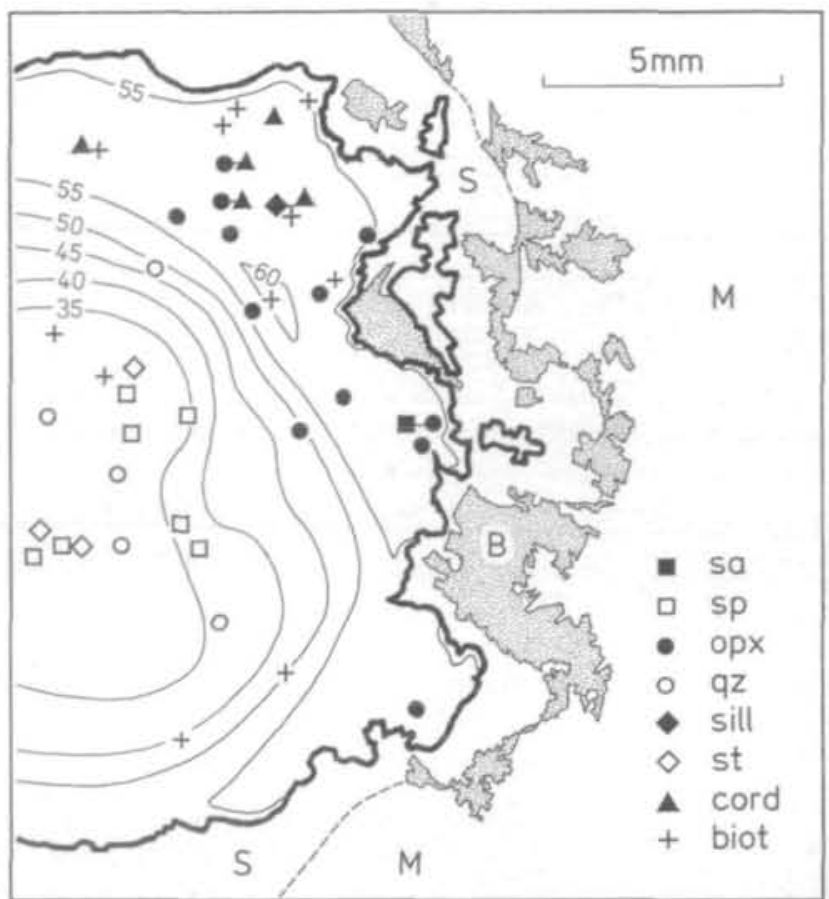

FIG. 2. Distribution of inclusion minerals in a garnet porphyroblast. TS100. S: area rich in symplectites. M: matrix of cordierite, biotite, sillimanite, sapphirine, quartz, orthopyroxene and feldspars. B: biotite corona. The garnet is contoured in values of $100 \mathrm{Mg} /\left(\mathrm{Mg}+\mathrm{Fe}^{2+}\right)$.

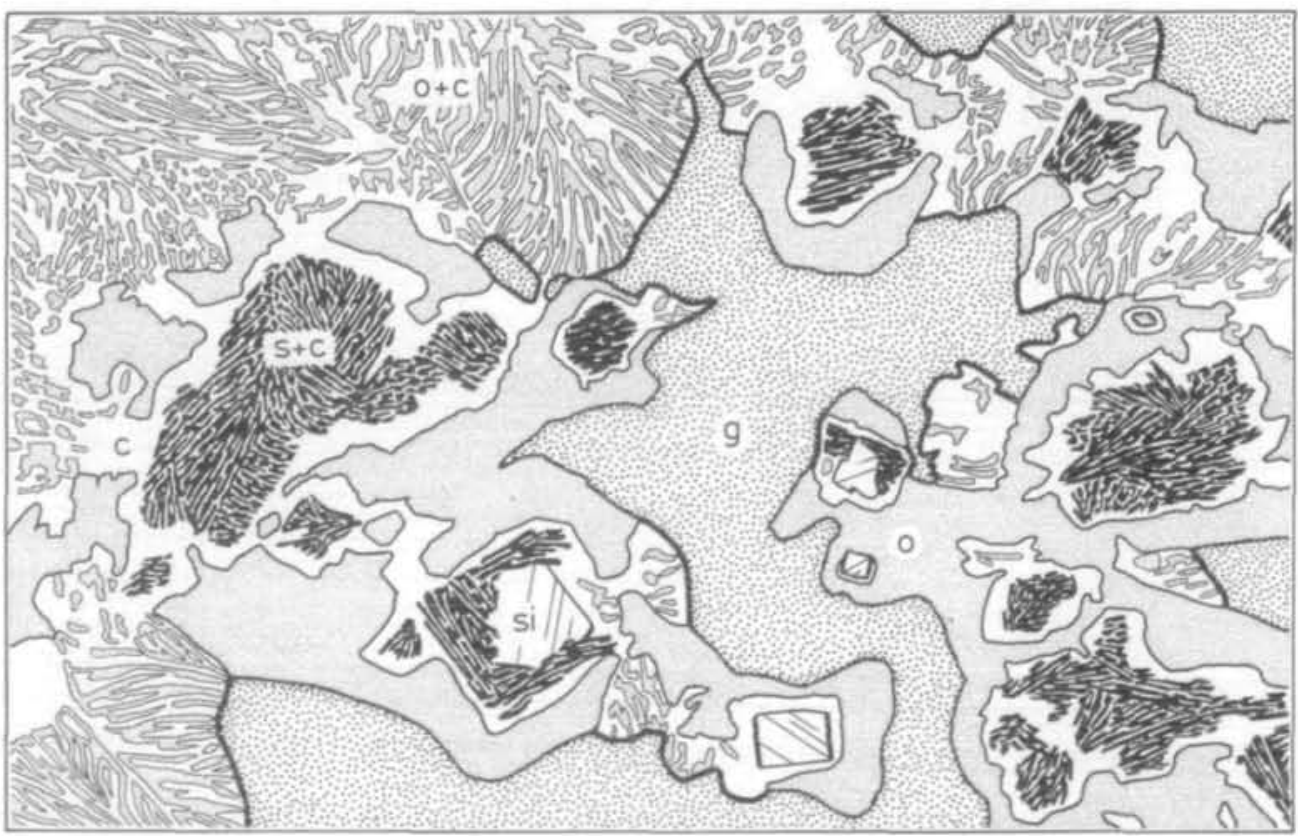

FIG. 3. Garnet-breakdown textures. TS100 (x70). g: garnet; o: orthopyroxene; si: sillimanite; o + c: orthopyroxene + cordierite symplectite; $s+c$; sapphirine + cordierite symplectite. The field of view was probably at one stage occupied entirely by garnet with quartz inclusions; mineralogy and textures were subsequently modified by reactions 13,17 and 20 (see text). 
TA B LE 2

Mineral assemblages of single-phase and composite inclusions in garnet

\begin{tabular}{|c|c|c|c|}
\hline $\begin{array}{l}\text { st } \\
\text { sp } \\
\text { sa } \\
\text { crm } \\
\text { sill } \\
\text { opx } \\
\text { qz } \\
\text { biot } \\
\text { plag } \\
\text { ilm } \\
\text { rut } \\
\text { ap }\end{array}$ & $\begin{array}{l}\text { st + sp* } \\
\text { st + sa* } \\
\text { sp + sa* } \\
\text { sp + crm } \\
\text { sp + cord } \\
\text { sp + biot } \\
\text { sp + plag } \\
\text { sp + ilm } \\
\text { sp + rut } \\
\text { sa + opx } \\
\text { sa + plag } \\
\text { crm + sill } \\
\text { crm + cord } \\
\text { crm + biot } \\
\text { sill + opx } \\
\text { sill + cord }\end{array}$ & $\begin{array}{l}\text { sill + biot } \\
\text { sill + plag } \\
\text { opx + cord } \\
\text { opx + biot } \\
\text { cord + biot } \\
\text { cord + plag } \\
\text { biot + plag } \\
\text { biot + ilm } \\
\text { biot + rut } \\
\text { plag + ksp }\end{array}$ & 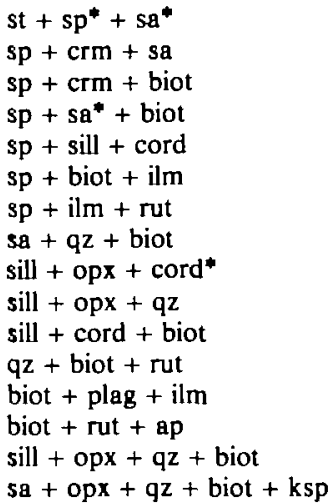 \\
\hline
\end{tabular}

* Phase forming distinct reaction rims.

There is a distinct zonal distribution of inclusion types within garnets (Fig. 2). Staurolite, spinel and quartz inclusions are generally concentrated in the cores of larger garnets, while inclusions containing sapphirine, orthopyroxene and sillimanite are more common near the rims (Fig. 2).

Sapphirine. In the matrix of the granulites, sapphirine occurs in three distinct forms: (1) in orthopyroxene + sapphirine symplectite near garnet (Fig. $4 b$ ); (2) in coronas of sapphirine + cordierite symplectite around sillimanite (Figs. 3, 4a, and Schreyer (1970) p. 159); (3) abundant, large ( $1-4 \mathrm{~mm}$ long) subhedral prismatic single twinned crystals, generally enclosed by cordierite (Figs. $4 a, 5 a, 5 b, 5 d$ ). Prismatic sapphirine is commonly closely associated with (and locally partially or totally enclosed by) prismatic orthopyroxene, but the two minerals are generally separated by a thin selvage of cordierite (Fig. 4a). Many sapphirine prisms are distinctly zoned, with their colour becoming gradually darker towards their rims. This zoning is less obvious where sapphirine is not in direct contact with cordierite. The dark rims tend to follow the grain boundaries, even where the latter are very irregular. Prismatic sapphirines locally enclose grains of biotite, spinel (Fig. $5 a$ ), corundum, sillimanite and orthopyroxene.

Common assemblages involving sapphirine included in garnet are (a) sapphirine + orthopyroxene, and (b) sapphirine + spinel \pm corundum (Fig. 6e). In (a), the sapphirine is invariably euhedral, unzoned and isolated from garnet by orthopyroxene (Fig. 6c). Composite sapphirine + orthopyroxene and sapphirine + spinel grains similar to (a) and (b) occur locally in the matrix cordierite near garnet and are presumed to be former inclusions subsequently exhumed during garnet resorption.

Sapphirine and quartz are not found in direct contact in the rock matrix. However, sapphirine and quartz were found in mutual grain contact in some composite inclusions in garnet (Fig. 6a, 6d). In one case (Fig. 6d), a euhedral sapphirine crystal is colour zoned in the opposite sense to matrix sapphirine. The assemblage sapphirine and quartz is rare and has been reported from only five other localities: (i) Peekskill, New York (Caporuscio \& Morse, 1978), (ii) Labwor, Uganda (Nixon et al., 1973), (iii) Wilson Lake, Labrador (Morse \& Talley, 1971; Meng \& Moore, 1972), (iv) Enderby Land, Antarctica (Dallwitz, 1968; Grew, 1980, 1982b; Ellis et al., 1980; Ellis, 1980), (v) Chogar, Siberia (Karsakov et al., 1975).

Orthopyroxene. Several textural types of orthopyroxene occur in the matrix of the rocks; 

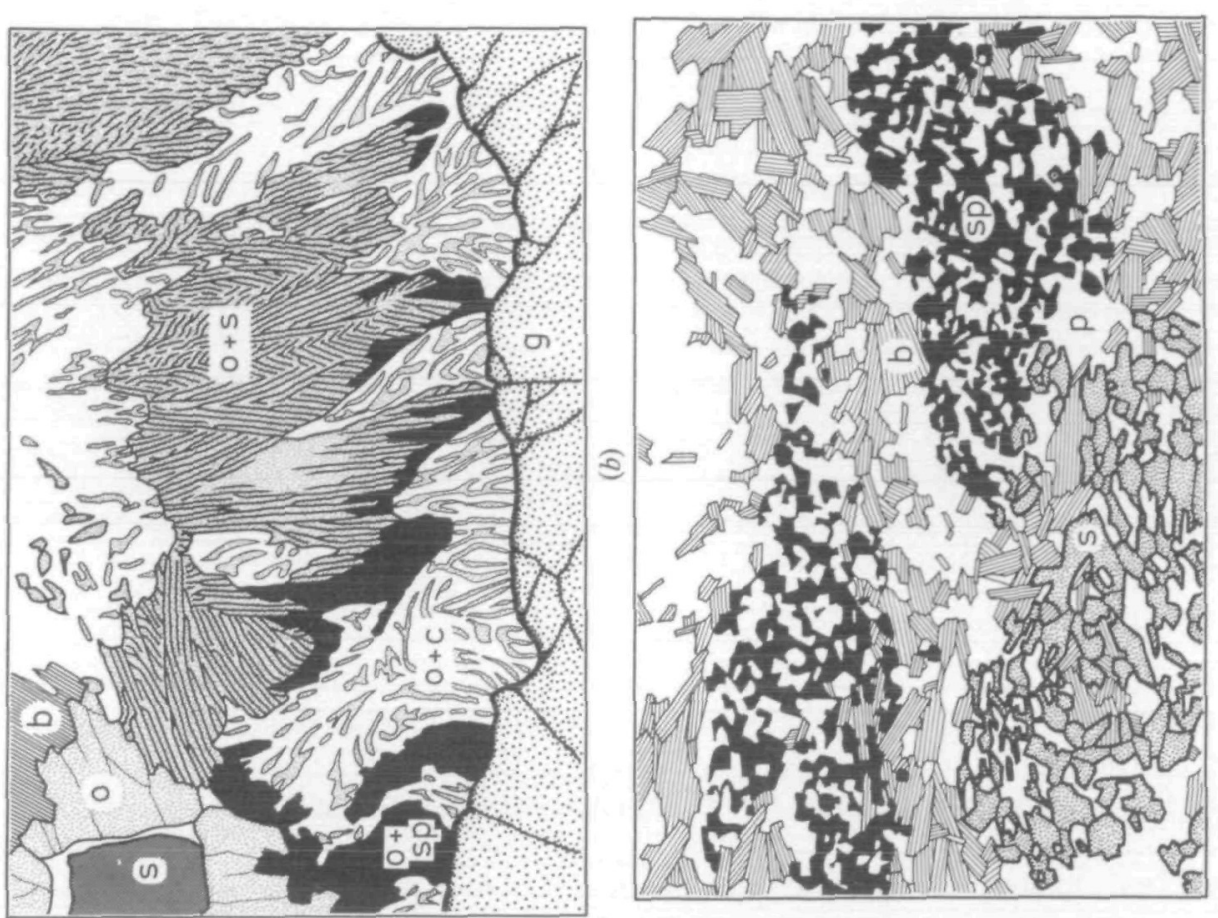

ㄷำ

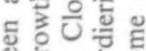

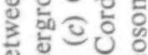

ํ.

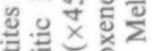

융응

है है की

o को

$+2-1$ 동

क

๖สู่

즌

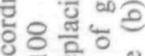

+ 望产的产

岂 + 带

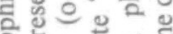

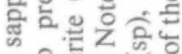

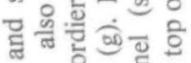

ว

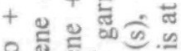

웣

는 옹을 들 잉

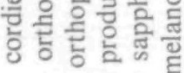

+ 믈 태용

뜨르를

क क्षँّ :

을

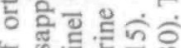

o

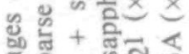

든

(ิ)

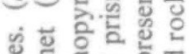

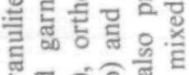
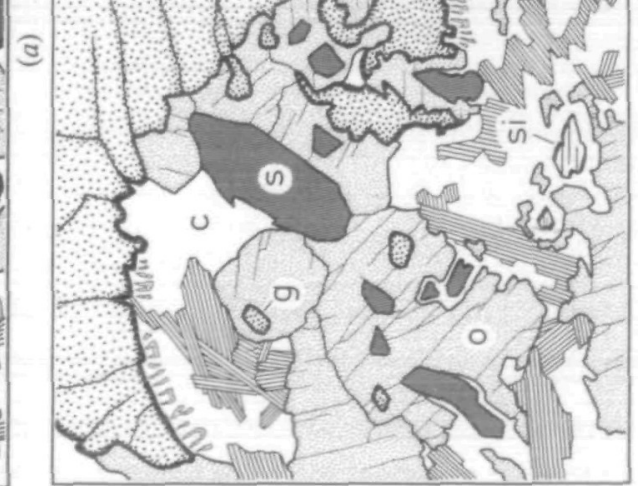

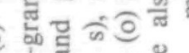

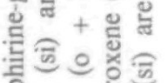

를 品产

듬

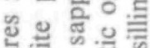

羟 + 可

区.

ब

ㄸํㅇㅎํ의

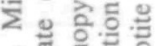

+ 出

高 
(1) Large (0.5-4 mm) subhedral, prismatic grains (Figs. $3 a, 4 a, 4 b)$ in contact with garnet, sapphirine, cordierite, biotite, feldspars and quartz. These grains are commonly surrounded by small biotite flakes (Fig. $5 b$ ), suggesting that some late breakdown to biotite has taken place. Prismatic orthopyroxenes locally enclose small grains of biotite and (rare) garnet (Fig. 4c). (2) Orthopyroxene + cordierite symplectite. (3) Orthopyroxene + sapphirine symplectite. (4) Orthopyroxene + spinel symplectite. Symplectites (2), (3) and (4) are found in coronas round garnet. (5) Small blebs in cordierite. (6) Reaction rims between quartz and coarse matrix biotite (Figs. $5 c, 5 d$ ). (7) Extensive, optically continuous fringes between garnet and sillimanite or its breakdown products in TS100 (Fig. 3). (8) in exhumed orthopyroxene + sapphirine inclusions near garnet.

In addition to isolated orthopyroxene and orthopyroxene + sapphirine inclusions (Fig. $6 c$ ), garnets in TS100 contain composite orthopyroxene + sillimanite inclusions, each consisting of a euhedral sillimanite prism totally enclosed by orthopyroxene (Fig. $6 b$ ). The texture described under (7) above is probably a version of this texture, somewhat modified by subsequent sillimanite replacement by cordierite \pm sapphirine.

Sillimanite. The bulk of the sillimanite in the rock matrix occurs as $1-3 \mathrm{~mm}$ long polycrystalline aggregates of prismatic crystals (Fig. 4a). Many of these aggregates have sub-rectangular shapes and strongly resemble the sillimanite pseudomorphs after kyanite described by Chinner \& Sweatman (1968) and Leyreloup et al. (1975).

Sillimanite inclusions in garnet occur both as single crystals (often with orthopyroxene, rarely spinel) and as aggregates of needles. Most matrix sillimanite aggregates and exhumed single-crystal inclusions are surrounded by a corona of sapphirine + cordierite symplectite (Figs. 3, 4a) and locally the sillimanite has been completely replaced (Fig. 3).

Cordierite. Cordierite is abundant. Grain size is variable; large twinned grains and small granules are common. It is found in contact with all minerals except staurolite, ilmenite and rutile. Cordierite grains are generally euhedral against quartz (Fig. $5 d$ ).

Cordierite is commonly included in garnet rims (Fig. 2) where it is locally intergrown with orthopyroxene as in the symplectitic coronas around garnets.

Biotite. Large orange-brown biotite flakes are distributed evenly throughout the matrix, where they make contact with all matrix minerals except sillimanite. Orthopyroxene reaction rims have developed locally along contacts with quartz (Fig. 5c). Small biotite flakes rim prismatic orthopyroxene (Fig. 5c) and form almost monomineralic shells enveloping the symplectic coronas around garnets (Fig. 2).

Biotite inclusions in garnet are common and show no zonal distribution, but close to garnet rims are paler, i.e. more magnesian, than matrix biotites.

Spinel. Green spinel is a minor phase, occurring mostly as inclusions in garnet. Composite spinel + staurolite inclusions (in which spinel in places rims staurolite) are common in garnet cores (Fig. 6f) while spinel + sapphirine and (in AL19, AL20) spinel + corundum inclusions are found near garnet rims. Where they occur together, spinel is generally rimmed by sapphirine, but the reverse has also been found. Isolated spinel inclusions are found in both garnet core and rim regions, even in rocks (e.g. TS100) in which spinel is concentrated in garnet cores (Fig. 2).

Outside garnet, spinel is rare and occurs in four textures: (1) inclusions in prismatic sapphirine (Fig. 5a); (2) orthopyroxene + spinel symplectite near garnet (Fig. 4b); (3) small irregular grains (possibly replacing sapphirine) in some sapphirine + cordierite intergrowth; (4) composite sapphirine + spinel grains (presumably exhumed inclusions) in cordierite close to garnet.

Corundum. Corundum occurs only as inclusions in garnet (AL19, AL20, Cod 12) (Fig. 6e) and prismatic sapphirine (AL20). 

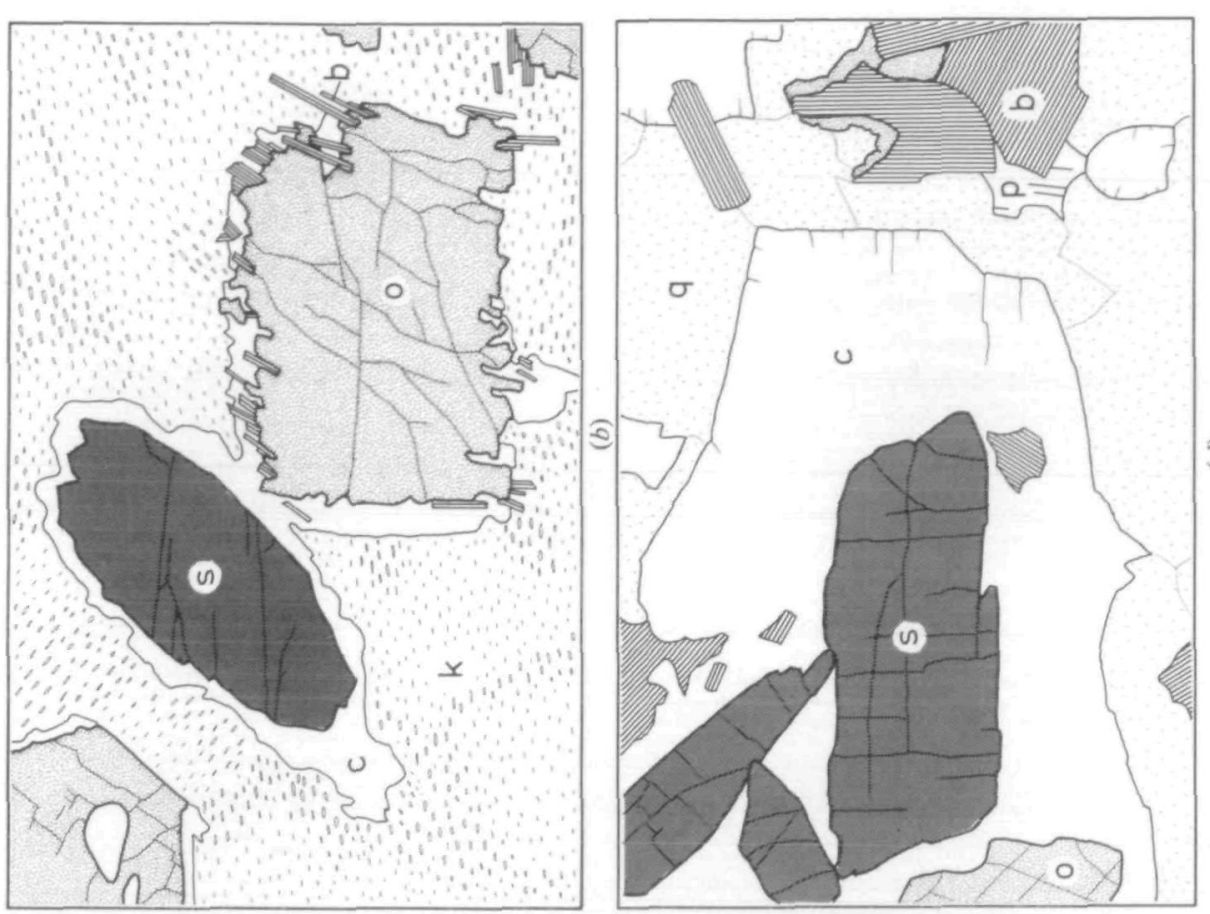

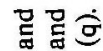

可题

응 준

는 홍

잉홍

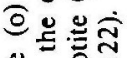

늠음

응ㅎㅀ용

言语鄚

등 可

ब.

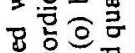

훙ㅎㅇ

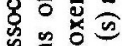

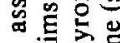

음즈을

홀ㅎㅇ음

들 宁

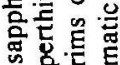

융동

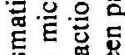

鸟范范

웡웡

ล․ $\div$
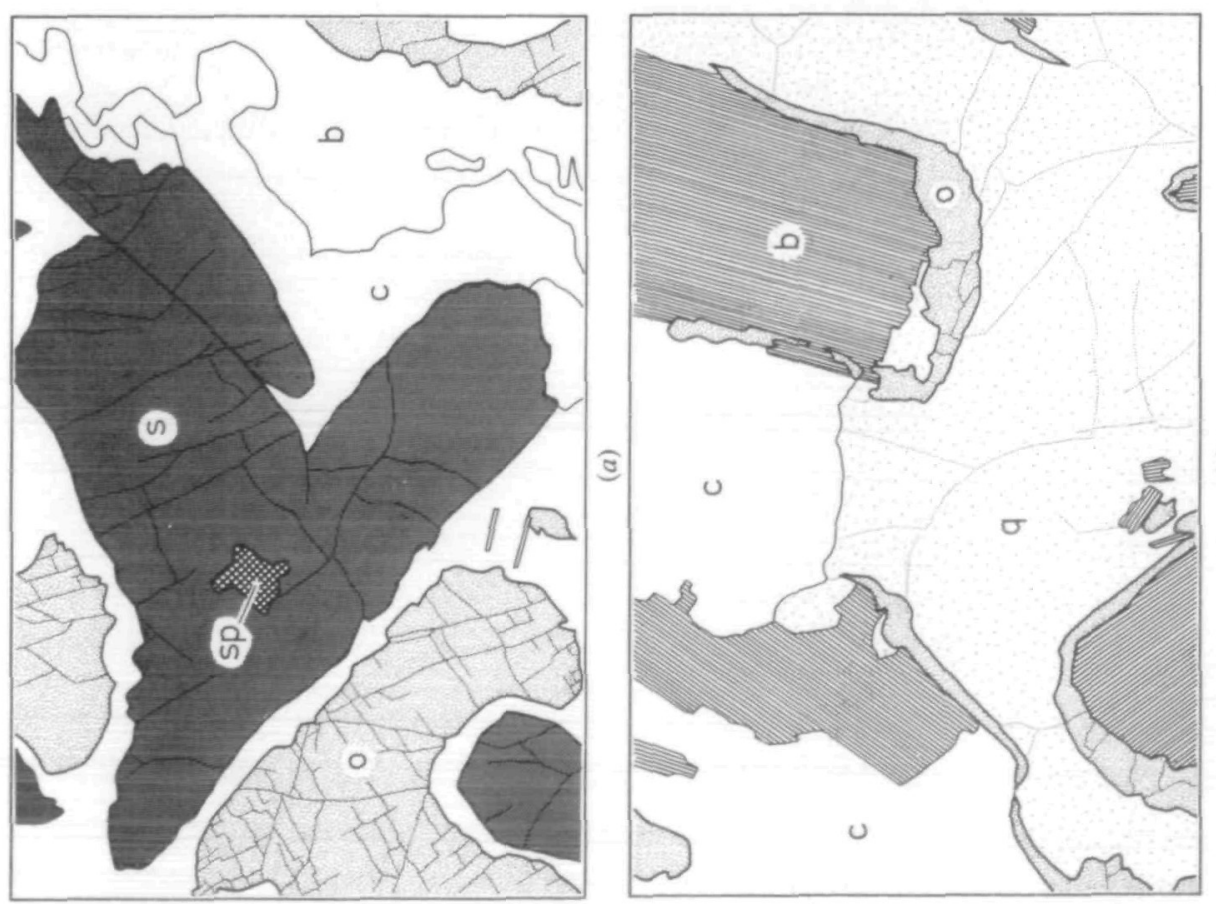

勾可产

言突

就

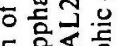

동 영

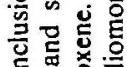

응는

혈온

등든

엉은을

을 응 영

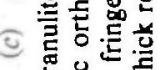

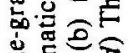

.

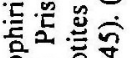

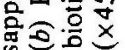

두궁유

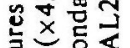

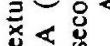

边

焉志

¿ $\dot{0}$.

的总言员 

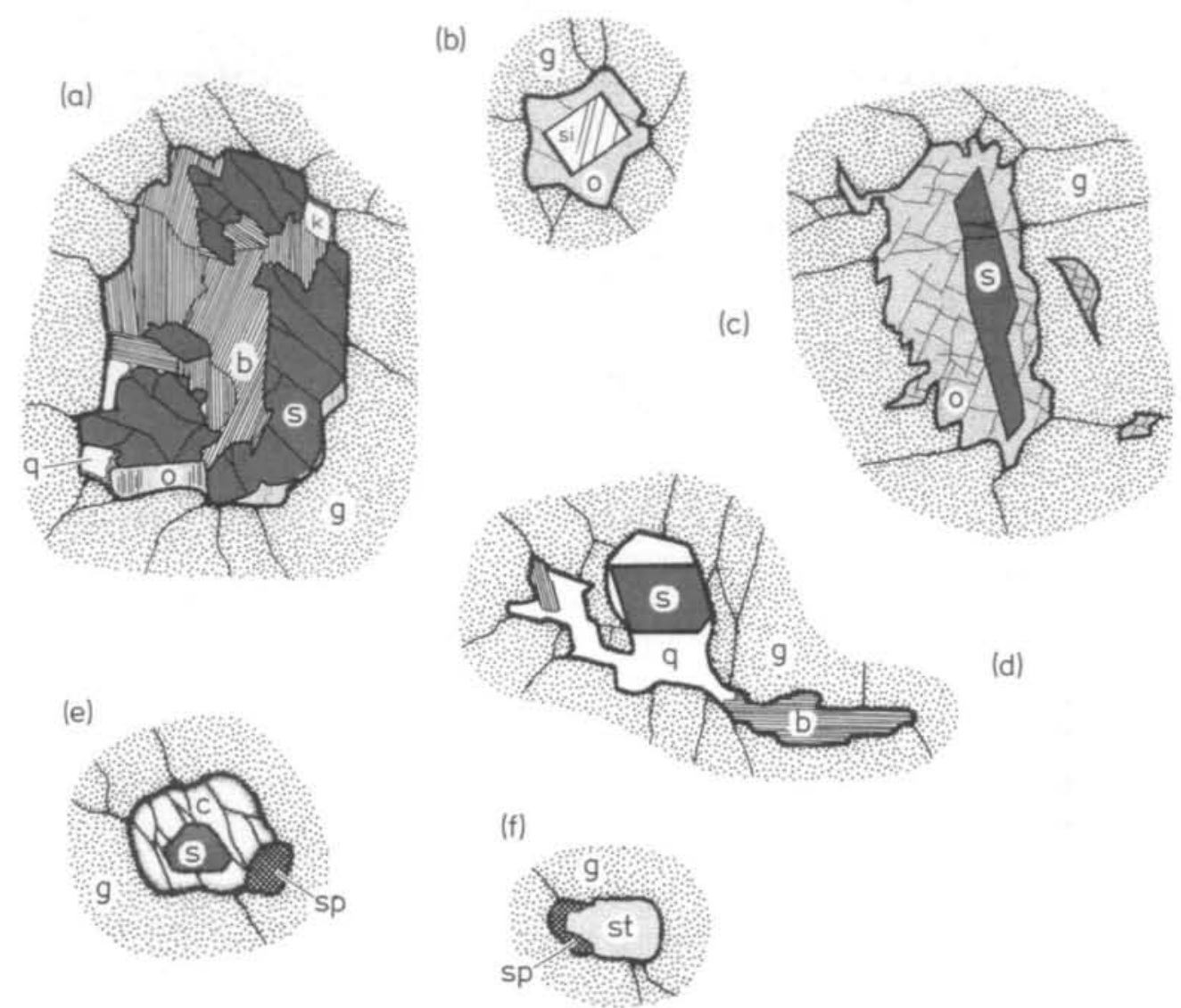

FIG. 6. Composite inclusions in garnet. s: sapphirine; o: orthopyroxene; si: sillimanite; b: biotite; q: quartz; k: K-feldspar; sp: spinel; st: staurolite. $(a),(b)$ and $(c)$ : in TS 100 garnet rims $(\times 20) ;(d)$ and $(e)$ : in AL20B garnet rims $(\times 20)$; $(f)$ : in TS100 garnet core $(\times 80)$.

Staurolite. The occurrence of staurolite is restricted to inclusions in garnet cores (TS100, AL20). It is commonly associated with spinel (Fig. $6 f$ ).

Quartz. Quartz is present in small quantities both in garnets and in the matrix of the rocks. Within garnet, quartz is in contact with biotite, orthopyroxene, sapphirine and garnet (Figs. $6 a, 6 d)$. In the matrix, quartz forms irregular, cuspate polycrystalline patches and is in contact with biotite, orthopyroxene, cordierite, $\mathrm{K}$-feldspar and plagioclase. Matrix sapphirine prisms are invariably separated from quartz by a rim of cordierite at least $0.2 \mathrm{~mm}$ thick (Fig. $5 d$ ). This cordierite is euhedral to quartz and seems to have grown at the expense of quartz and sapphirine.

Plagioclase. Small, twinned, locally strained plagioclase grains are distributed sporadically in the garnets and matrix.

$K$-feldspar. The $\mathrm{K}$-feldspar is a microperthite with a blebby exsolution texture (Fig. $5 b$ ). In the matrix, the grain size is generally large $(1-4 \mathrm{~mm})$, but small $\mathrm{K}$-feldspars are found in composite inclusions in garnet (Fig. 6a). The margins of some matrix $\mathrm{K}$-feldspars have been locally embayed by myrmekite.

Muscovite. Small patches of retrogressive sericite and coarser muscovite occur near late fractures in TS 100 .

Ilmenite, rutile, apatite. These minerals only occur as inclusions in garnet. 


\section{(b) Schist (AL41)}

This sample is texturally and mineralogically similar to those described above. The main differences are that AL41 contains (a) much more sillimanite, and hence much more sapphirine + cordierite symplectite, (b) no coarse biotite, (c) very few (and smaller) prismatic sapphirine grains, (d) anthophyllite, but no orthopyroxene. The anthophyllite occurs both as tiny blebs in cordierite near garnet (where it presumably replaces former symplectitic orthopyroxene) and as aggregates of aligned prisms in 1-2 $\mathrm{mm}$ long rectangular patches of anthophyllite \pm talc \pm phlogopite which are probably pseudomorphs after prismatic orthopyroxene.

Thus, AL41 would seem to be a sillimanite-rich variety of the sapphirine-granulite that has undergone some retrograde hydration.

\section{(c) Mixed rocks (AL19, Cod6A)}

The dark part of AL19 is sapphirine-granulite, as described in (a), above. The pale part of AL19 consists mainly of granular quartz, plagioclase (bytownite), and sub-poikilitic sector-twinned cordierite. Bands rich in small anhedral garnets and aggregates of sillimanite prisms define a crude foliation. Green spinel occurs locally in cordierite near sillimanite, but does not touch quartz.

The dark lenses in Cod6A are texturally and mineralogically different from the sapphirine-granulites described above. The minerals have a uniformly small grain size. Ellipsoidal patches (5 mm long) of granular sapphirine + plagioclase are embedded in a matrix of quartz + plagioclase + K-feldspar + garnet + orthopyroxene + biotite (Fig. $4 d$ ). Spinel appears instead of sapphirine within $1 \mathrm{~mm}$ from the edge of each lens.

The leucocratic portion of Cod6A consists of small $(0.5 \mathrm{~mm})$ rounded garnets and orthopyroxenes in a coarse, granular non-foliated matrix of quartz, perthite, plagioclase (oligoclase) and biotite.

\section{WHOLE ROCK CHEMISTRY}

Bulk analyses of sapphirine-granulites from the Bresciadega locality indicate that these rocks have low $\mathrm{SiO}_{2}$ ( $\sim 40$ wt. per cent), high $\mathrm{Al}_{2} \mathrm{O}_{3}$ ( $\sim 25$ wt. per cent), high $\mathrm{MgO}$ ( $\sim 17$ wt. per cent) and high $\mathrm{Mg} /(\mathrm{Fe}+\mathrm{Mg})(\sim 0.76)$ (Cornelius \& Dittler, 1929; Barker, 1964).

Sapphirine rocks with similar compositions have been described by Lal et al. (1978) who present evidence that their rocks formed as $\mathrm{Mg}$, Al-rich restites left after removal of $\mathrm{Fe}$, $\mathrm{Si}$-rich granitic liquids produced by $75-85$ per cent partial melting of pelitic schist of average composition. Origins proposed for $\mathbf{M g}$, Al-rich sapphirine bearing rocks from other areas include (i) isochemical metamorphism of unusual sedimentary bulk compositions (e.g. McKie, 1959; Meng \& Moore, 1972), (ii) metamorphism of hydrothermally altered basalts (e.g. Wilson, 1971), (iii) Mg-metasomatism of pelites (e.g. Muthuswami, 1949), and (iv) metamorphism of ultramafic rocks that have suffered metasomatism (e.g. Lensch, 1971). Cornelius \& Dittler (1929) and Barker (1964) both favour explanation (iv) for the Codera rocks, but new evidence is presented below in support of a partial melting origin.

\section{MINERAL CHEMISTRY}

The mineral chemistry is discussed in detail because the thermodynamic calculations depend on it and very few analyses from these rocks have been published to date. Also, large variations in the compositions of certain minerals occur within each sample; these are reflected both in compositional zoning of individual grains and in differences in composition between grains of the same mineral in different textural settings. 


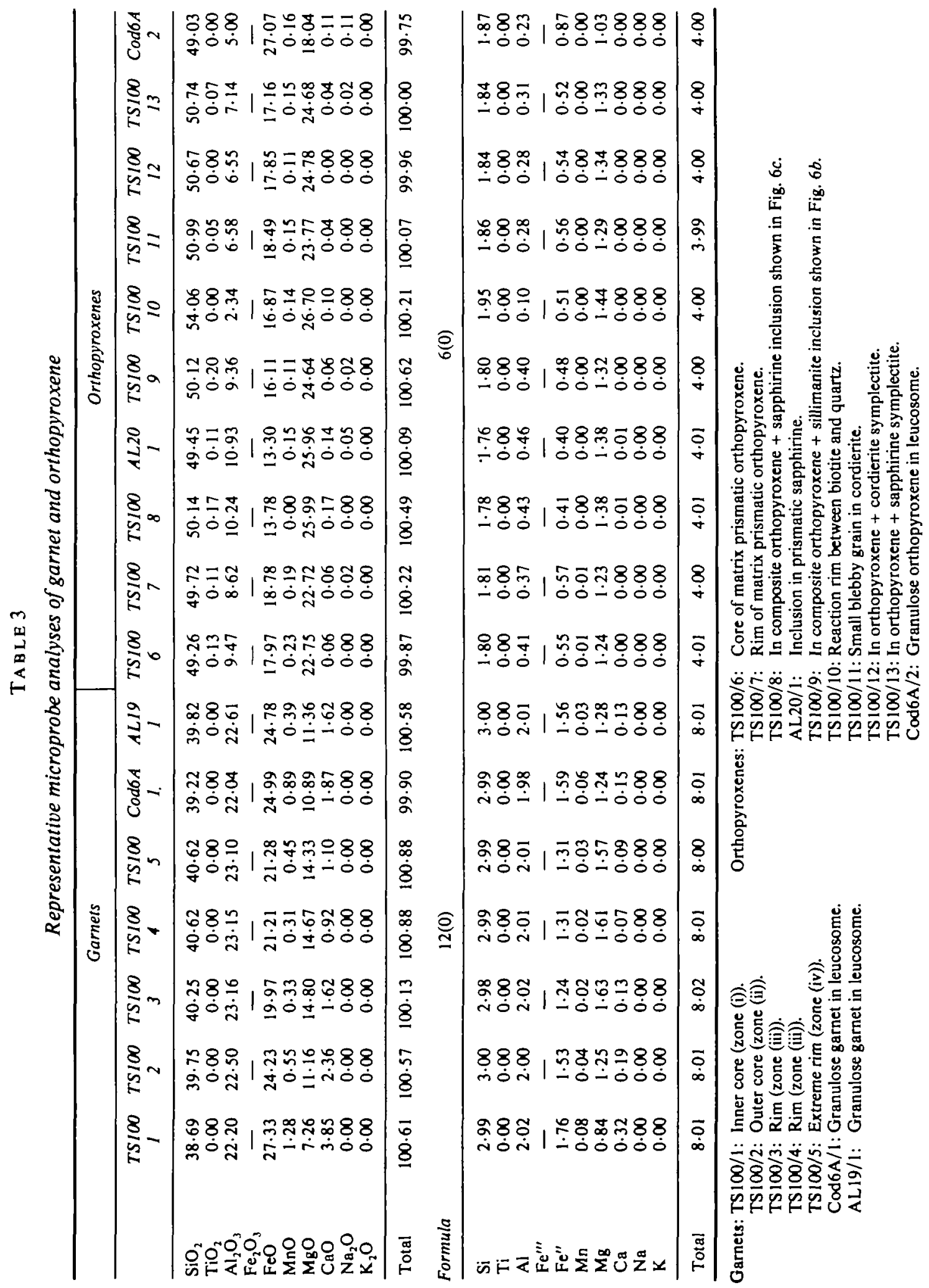




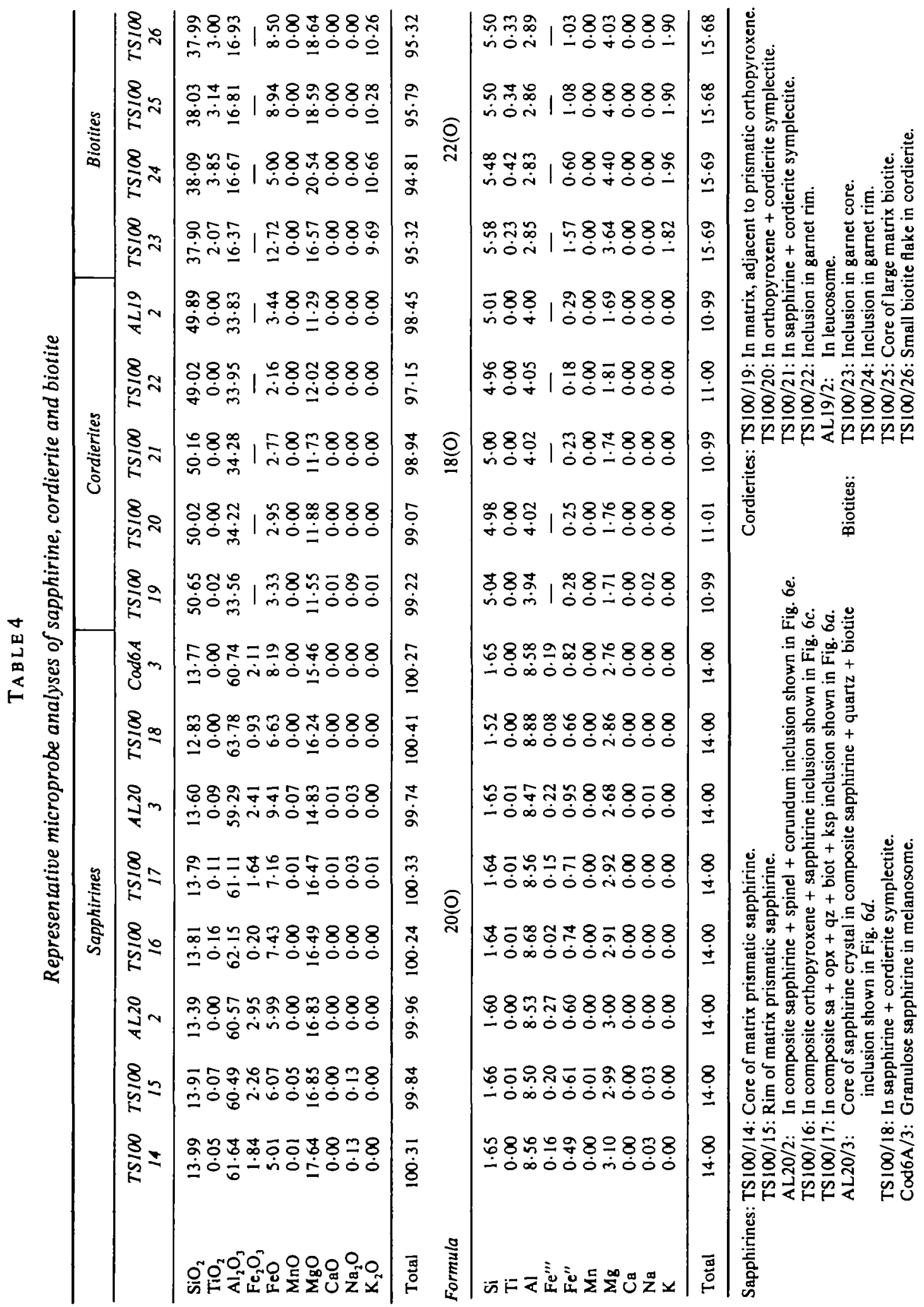




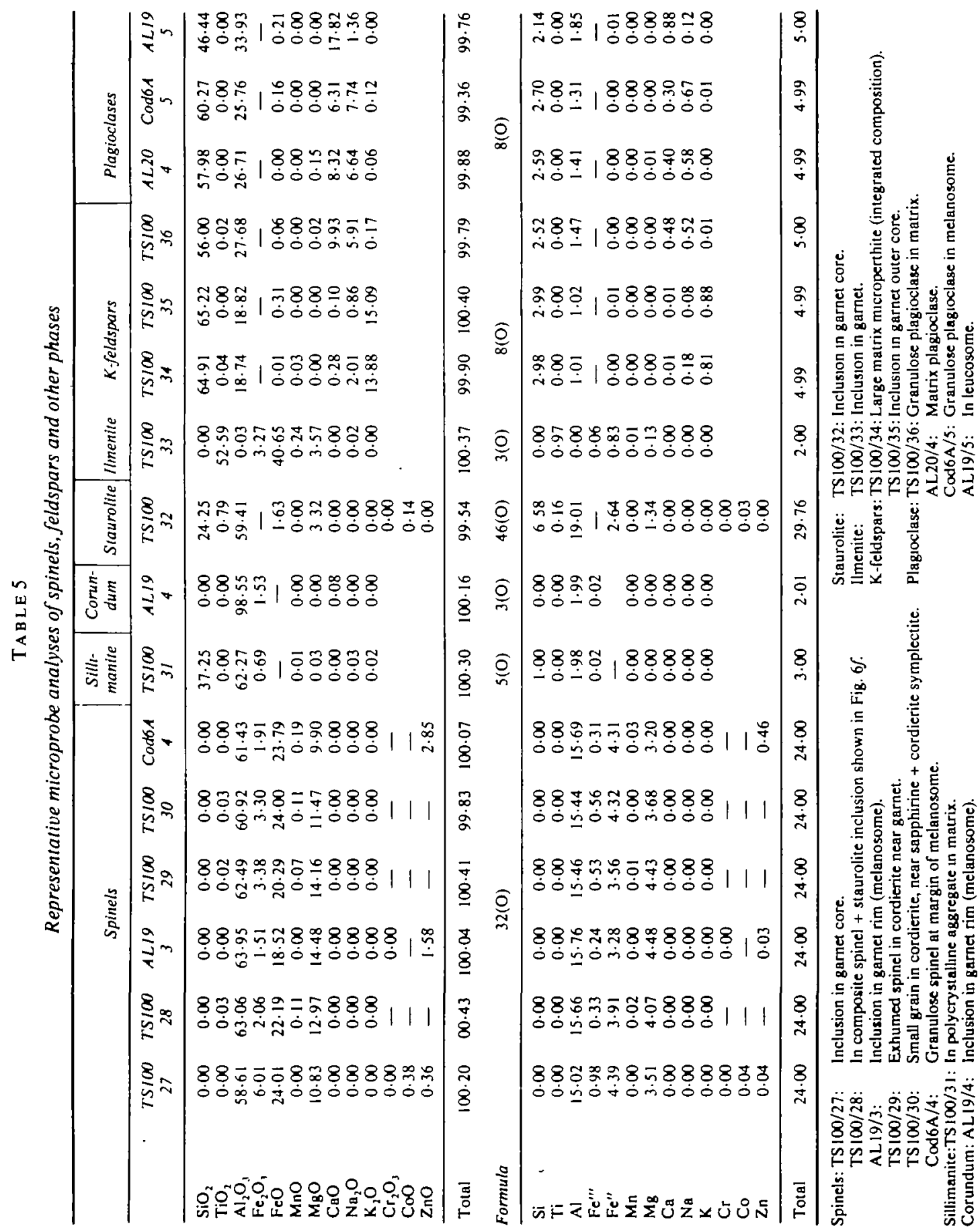


Minerals were analysed using an energy dispersive electron-microprobe at the Department of Earth Sciences, University of Cambridge. Accelerating potential was $20 \mathrm{kV}$ and live counting time $80 \mathrm{~s}$. Peaks were measured and processed by iterative peak stripping (Statham, 1976) and corrected using the method of Sweatman \& Long (1969). Precision and accuracy of analyses are similar to those listed by Dunham \& Wilkinson (1978).

Representative analyses of the minerals in their various textural settings are presented in Tables 3, 4, and 5. Chemographic relationships among iron-magnesium silicates are shown in Fig. 7, and the extent of $\mathrm{Mg}=\mathrm{Fe}$ and $(\mathrm{Mg}, \mathrm{Fe}), \mathrm{Si}=\mathrm{Al}, \mathrm{Al}$ substitutions are summarized in histograms (Figs. 8, 9). Compositions of minerals in direct contact are plotted on AFM projections from quartz and $\mathrm{K}$-feldspar (Figs. 10,11) and a projection from $\mathrm{Al}_{2} \mathrm{SiO}_{3}$ onto the orthopyroxene-spinel plane of the $\mathrm{FeO}-\mathrm{MgO}-\mathrm{Al}_{2} \mathrm{O}_{3}-\mathrm{SiO}_{2}$ tetrahedron (Fig. 12).

Garnet. Of all the minerals, garnet shows the greatest range in $\mathrm{Mg} /\left(\mathrm{Mg}+\mathrm{Fe}^{2+}\right)$ ratio (= ' $M$ value') (Fig. 8). Detailed analysis (130 spots) of a garnet porphyroblast in TS100 has revealed strong zoning (Figs. 2, 13). Four successive zones can be recognized: (1) a core region of roughly constant $M$ value ( $\sim 0.32)$ and appreciable $\mathrm{Ca}$ and $\mathrm{Mn}$ concentration; (2) a zone of decreasing $\mathrm{Ca}$ and $\mathrm{Mn}$ and sharply increasing $M$ value (as high as 0.61 at one point); (3) a rim of varying width with low $\mathrm{Ca}$ and $\mathrm{Mn}$ concentrations and high but gently decreasing $M$ values towards the edge, and (4) a $0.1-0.3 \mathrm{~mm}$ wide edge showing a small but abrupt decrease in $M$ value.

There is a close correspondence between inclusion mineralogy and the composition of the garnet host adjacent to inclusions (Fig. 2).

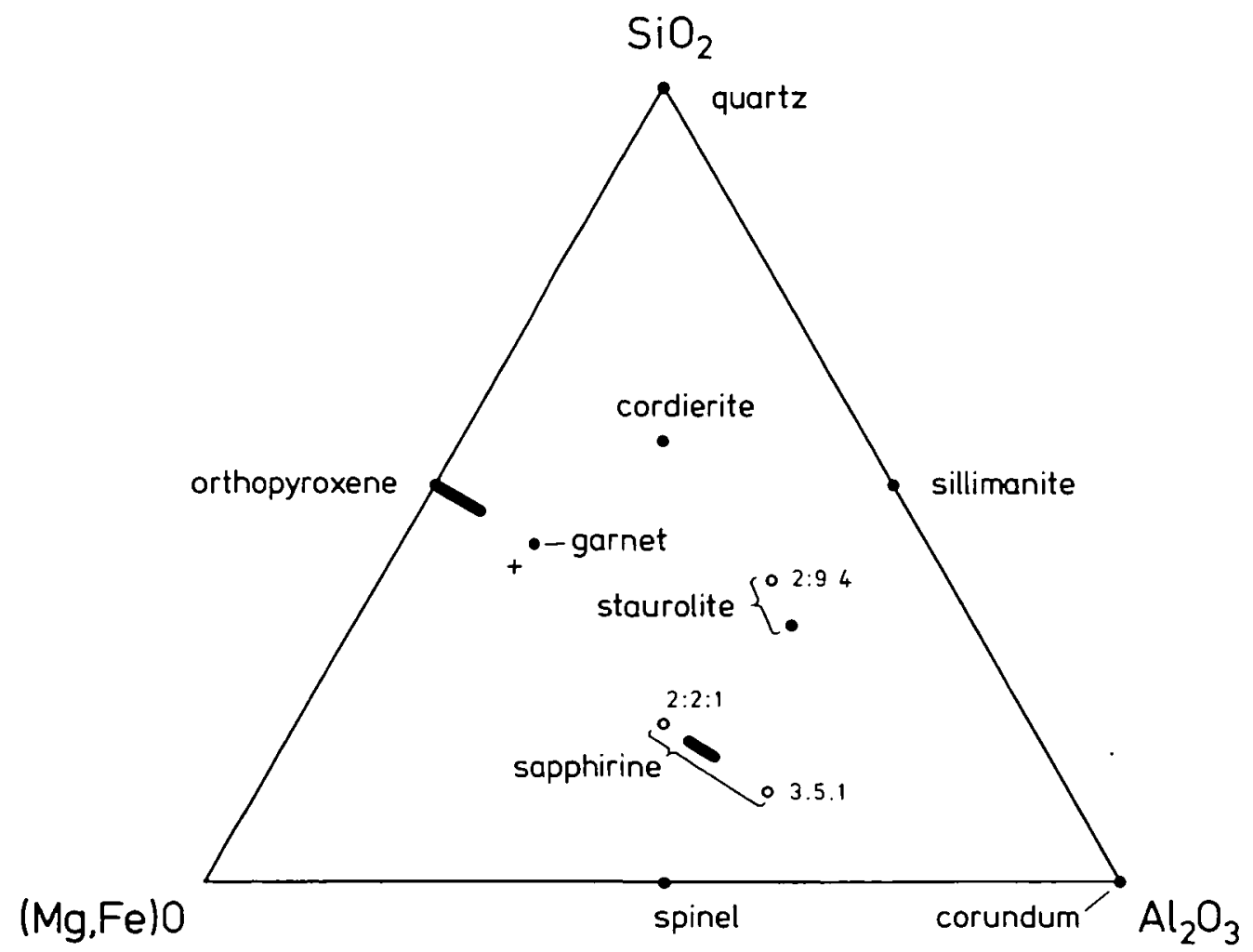

Fig. 7. Chemographic relationships among phases in the system $(\mathrm{Mg}, \mathrm{Fe}) \mathrm{O}-\mathrm{Al}_{2} \mathrm{O}_{3}-\mathrm{SiO}_{2}$. +: Integrated composition of sapphirine + orthopyroxene symplectite. 
IN MATRIX $\quad$ IN SYMPLECTITES INCLUSIONS IN GT
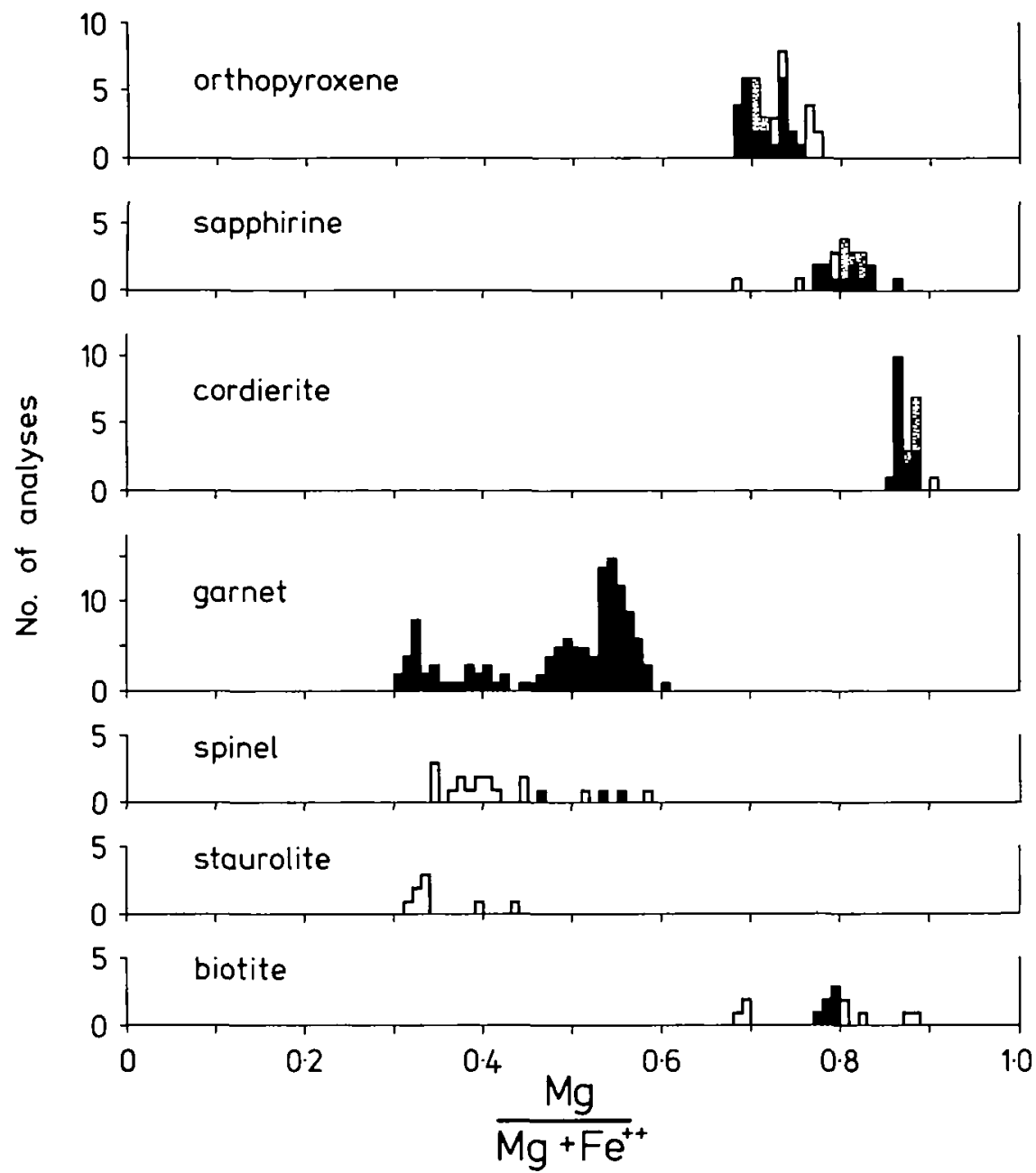

Fio. 8. Histograms showing number of analyses vs. $\mathrm{Mg} /\left(\mathrm{Mg}+\mathrm{Fe}^{2+}\right)$ for ferromagnesian minerals in sapphirine-granulite TS 100 .

Zones 1, 2 and 3 are considered to be primary garnet growth zones, as the boundaries separating them are smooth and concentric (Fig. 2). Garnet resorption has resulted in erosion and locally complete removal of the $\mathrm{Mg}$-rich rim (zone 3). Zone 4, however, closely follows the convoluted garnet grain boundary and maintains its width even where zone 3 is missing. These features suggest that zone 4 developed during garnet resorption, although it shows none of the Mn-enrichment commonly displayed by resorbed garnets (e.g. Grant \& Weiblen, 1971; De Bethune et al., 1975).

Woodsworth (1977) has been shown that prograde garnet zoning profiles may be smoothed or homogenized at high grade. Clearly, no such homogenization has been effective in these garnets even though temperatures of $800^{\circ} \mathrm{C}$. were attained (see below). It is possible, nonetheless, that some diffusion between core, and rim did take place after garnet growth, in which case zone 2 would have been initially narrower than at present. 


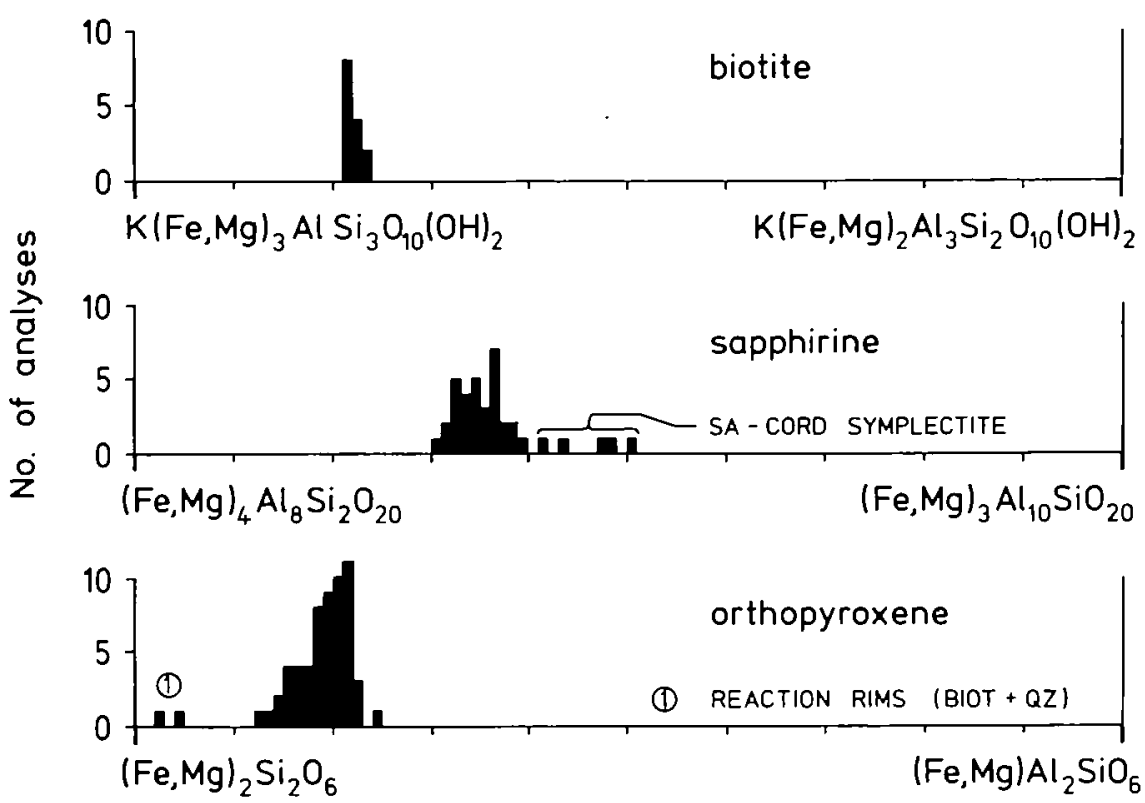

FIG. 9. Histograms showing number of analyses vs. the extent of Tschermak substitution in orthopyroxene, sapphirine and biotite.

Garnets in the pale parts of the mixed rocks AL19 and Cod6A have $M$ values clustering in the ranges $0.43-0.47$ and $0.26-0.28$, respectively.

Sapphirine. Natural sapphirine compositions can be considered as $\mathrm{Mg}_{4} \mathrm{Al}_{8} \mathrm{Si}_{2} \mathrm{O}_{20}$ (2:2:1 sapphirine) modified by $\mathrm{Mg}=\mathrm{Fe}^{2+},\left(\mathrm{Mg}, \mathrm{Fe}^{2+}\right), \mathrm{Si}=\mathrm{Al}, \mathrm{Al}$ (Tschermak) and $\mathrm{Al}=\mathrm{Fe}^{3+}$ substitutions (Deer et al., 1978). All three substitutions are represented in the sapphirines studied here. The sapphirine analyses are calculated on the basis of 20 oxygens. With all iron as $\mathrm{Fe}^{2+}$, cation totals generally exceed 14.00 , implying that some $\mathrm{Fe}^{3+}$ is present (see Ellis et al., 1980; Grew, 1980). Further evidence for this is the fact that (Al-8) > (6-Si-Mg-Fe) with all iron as $\mathrm{Fe}^{2+}$. The $\mathrm{Fe}^{3+}$ contents of sapphirines are estimated by making the sum of $\mathrm{Si}, \mathrm{Ti}$, $\mathrm{Al}, \mathrm{Fe}^{3+}, \mathrm{Fe}^{2+}, \mathrm{Mn}, \mathrm{Mg}=14.00$ per 20 oxygens. The $\mathrm{Fe}^{3+}$ contents generated by this method are probably fairly accurate as many of the analyses satisfy or nearly satisfy the criterion $\mathrm{Al}$ (vi) $+\mathrm{Fe}^{3+}=\mathrm{Al}$ (iv) (Higgins et al., 1979).

The matrix prismatic sapphirines of the granulites are compositionally zoned, and show a smoth decrease in $M$ value from core $(0.86)$ to rim (0.80) (Fig. 14B), which correlates with the colour zoning, and 3:5:1 sapphirine contents fall in the range 30-40 per cent (Fig. 9). There is no significant $\mathrm{Si}$ - and $\mathrm{Al}$-zoning.

The sapphirine inclusions of Fig. $6 d$ are zoned in that $\mathrm{Al}$ content and $M$ value increase from core to rim (Fig. 14C). Euhedral sapphirine inclusions in orthopyroxenes are not zoned.

Compared to prismatic grains, sapphirines from sapphirine + cordierite symplectites have similar $\mathrm{Mg}$ and Fe contents but are more aluminous (Fig. 9).

Despite having comparatively low $\mathrm{Al}$ contents, the prismatic sapphirine cores in AL20B must have been saturated with $\mathrm{Al}$ at the time of formation as they contain inclusions of both spinel and corundum. The Al content of sapphirine in this limiting assemblage is controlled by the equilibrium:

$$
\underset{\text { sapphirine 1 }}{\mathrm{Mg}_{4} \mathrm{Al}_{8} \mathrm{Si}_{2} \mathrm{O}_{20}}+\underset{\text { corundum }}{4 \mathrm{Al}_{2} \mathrm{O}_{3}}+\underset{\text { spinel }}{2} \underset{\mathrm{MgAl}_{2} \mathrm{O}_{4}}{2}=\underset{\text { sapphirine 2 }}{2 \mathrm{Mg}_{3} \mathrm{Al}_{10} \mathrm{SiO}_{20}}
$$


The Al-rich symplectitic sapphirines cannot have crystallized under the same metamorphic conditions as the prismatic sapphirine cores since the same value of the equilibrium constant of (1) cannot have applied during growth of the two types. The sapphirines of Cod6A have a fairly uniform $M$ value (between 0.71 and 0.75 but vary in the degree of Tschermak substitution (28-52 per cent 3:5:1 sapphirine).

Orthopyroxene. The compositions of all analysed orthopyroxenes fall close to the plane En-Fs-MgTs-Fe ${ }^{2+}$ Ts. Cation totals are close to 4.00 per 6 oxygens, implying that little $\mathrm{Fe}^{3+}$ is present. $\mathrm{Ca}$ contents are very low ( $<0.2$ wt. per cent).

The main compositional variable is the degree of Tschermak substitution; $(\mathrm{Mg}, \mathrm{Fe}) \mathrm{Al}_{2} \mathrm{SiO}_{6}$ contents range from 3 to 23 per cent (Fig. 9). The orthopyroxenes with the highest Al contents ( $>21$ per cent $\mathrm{Ts})$ form inclusions in prismatic sapphirine and composite orthopyroxene + sapphirine inclusions in garnet. Matrix prismatic orthopyroxenes and orthopyroxene fringes around sillimanite in garnet also have high $\mathrm{Al}$ contents, typically between 17 and 21 per cent Ts. Symplectitic orthopyroxenes have significantly lower Al contents, ranging from 12 to 16 per cent Ts. The orthopyroxenes with the lowest $\mathrm{Al}$ contents ( 3 to 5 per cent Ts) form reaction rims between biotite and quartz.

If garnet and orthopyroxene coexist, the Al content of the orthopyroxene is controlled by the equilibrium:

$$
\underset{\text { orthopyroxene }}{\mathrm{Mg}_{3} \mathrm{Al}_{2} \mathrm{Si}_{3} \mathrm{O}_{12}}=\underset{\text { garnet }}{\mathrm{Mg}_{3} \mathrm{Al}_{2} \mathrm{Si}_{3} \mathrm{O}_{12}}
$$

With the exception of the fringes between biotite and quartz, all types of orthopyroxene mentioned above occur close to garnet. The large differences between their Al contents imply

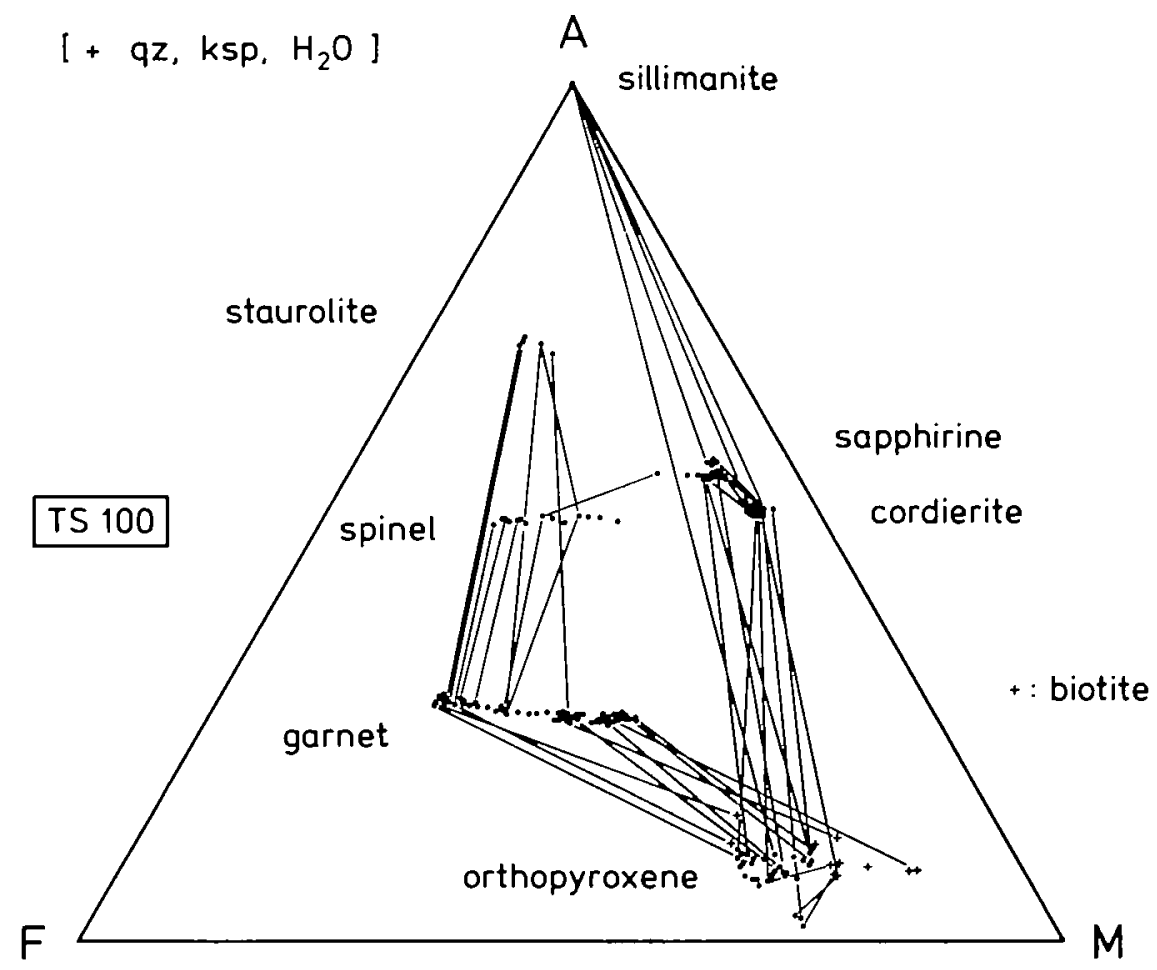

FIG. 10. Compositions of contiguous mineral grains in TS100 plotted on an AFM projection from quartz and K-feldspar. 
that these orthopyroxenes must have grown under different $P-T$ conditions if they equilibrated with garnet. This is supported by the observation that although the symplectitic orthopyroxenes are less aluminous than prismatic orthopyroxenes, symplectitic sapphirines are more aluminous than prismatic sapphirines; the equilibrium constant of

$$
\underset{\mathrm{Opx}}{\mathrm{MgAl}_{2} \mathrm{SiO}_{6}}+\underset{\mathrm{Sa}}{\mathrm{Mg}_{4} \mathrm{Al}_{8} \mathrm{Si}_{2} \mathrm{O}_{20}}=\underset{\mathrm{Opx}}{\mathrm{Mg}_{2} \mathrm{Si}_{2} \mathrm{O}_{6}}+\underset{\mathrm{Sa}}{\mathrm{Mg}_{3} \mathrm{Al}_{10} \mathrm{SiO}_{20}}
$$

must therefore have changed between prismatic mineral growth and symplectite development. Analysed orthopyroxenes show a moderate range in the degree of $\mathrm{Mg}-\mathrm{Fe}$ substitution (Fig. 8). In the granulites, matrix prismatic orthopyroxenes have the lowest and most variable $M$ values, and inclusions in garnet rims have the highest. Other textural types have intermediate values.

Prismatic orthopyroxenes show no distinct compositional zoning (Fig. 14A) but a slight decrease in $\mathrm{Al}$ is observed towards the rims of some grains.

Orthopyroxenes in Cod6A have $M$ values of between 0.51 and 0.55 and contain between 11 and 13 per cent Ts.

Cordierite. The cordierites are found to have fairly uniform composition within each rock ( $M$ values of between 0.85 and 0.89 in TS100; between 0.88 and 0.91 in AL20B) irrespective of local mineral assemblage or grain size. One exception is a TS 100 cordierite inclusion in garnet which has a $M$ value of 0.91 . Most analyses show c. 0.1 wt. per cent $\mathrm{Na}_{2} \mathrm{O}$. No zoning has been detected. The cordierite of AL20B was found to contain $0.80 \mathrm{wt}$. per cent $\mathrm{H}_{2} \mathrm{O}$ by gravimetric analysis, which corresponds to 0.265 moles $\mathrm{H}_{2} \mathrm{O}$ per mole cordierite.

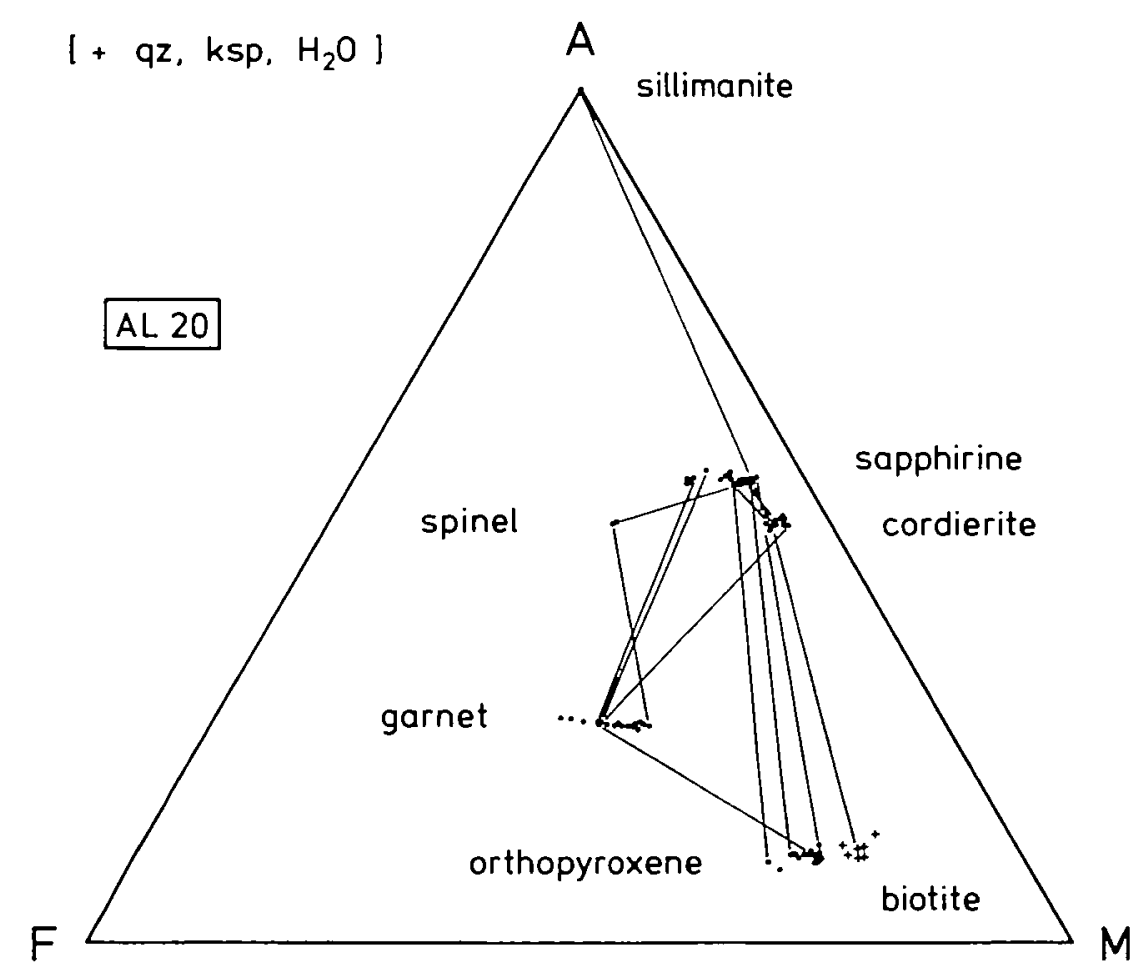

FIG. 11. Compositions of contiguous mineral grains in AL20B plotted on an AFM projection from quartz and K-feldspar. 


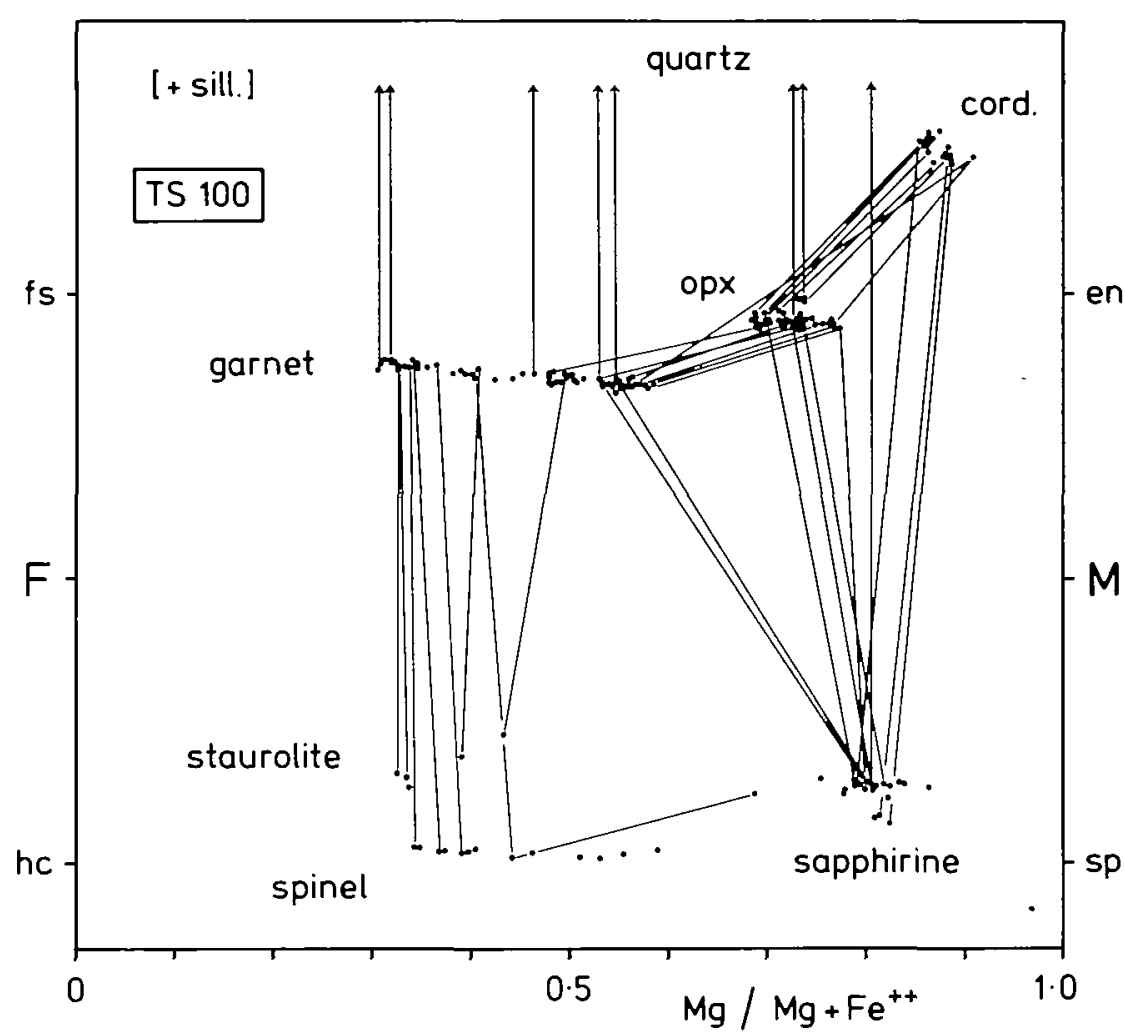

FIG. 12. Compositions of contiguous mineral grains in $\mathrm{TS} 100$ plotted on a projection from $\mathrm{Al}_{2} \mathrm{SiO}$, onto the enstatite-ferrosilite-spinel-hercynite plane of the FMAS tetrahedron ('opx-spinel' projection).

Biotite. Matrix biotites from a given sample are extremely uniform in terms of both $\mathrm{Mg}-\mathrm{Fe}$ - and Tschermak-substitutions (Figs. 8,9) but contain variable amounts of Ti. By contrast, $M$ values of biotite inclusions in TS100 garnets are highly variable and reflect the composition of the enclosing garnet in the vicinity of each inclusion; values range from 0.68 (in garnet cores) to 0.88 (in garnet rims).

Biotites in the dark lens of Cod6A have generally higher $M$ values $(\sim 0.78)$, higher $\mathrm{Al}$ and lower Ti than those in the leucocratic matrix (with $M$ values from $0.59-0.64$ ).

Biotites were not analysed for halogens. The presence of 0.7 wt. per cent in a biotite analysed by Barker (1964) suggests that all the biotites studied here probably have significant F substituting for $(\mathrm{OH})$.

Spinel. The spinels are essentially solid solutions of $\mathrm{Mg}$-spinel, hercynite and magnetite, but contain minor amounts of $\mathrm{Co}, \mathrm{Zn}$, and $\mathrm{Mn}$. $\mathrm{Cr}$ and $\mathrm{Ti}$ could not be detected. $\mathrm{Fe}^{3+}$ concentrations were calculated assuming a cation total of 24.00 per 32 oxygens.

Spinel inclusions, like biotite, show a systematic variation in $M$ value with the composition of the enclosing garnet. Compositions range from $\mathrm{Sp}_{39} \mathrm{Hc}_{60} \mathrm{Mt}_{4} \mathrm{Gahn}_{1}$ (in garnet cores) to $\mathrm{Sp}_{61} \mathrm{Hc}_{34} \mathrm{Mt}_{4} \mathrm{Gahn}_{1}$ (in garnet rims). Some $\mathrm{Mg}$-rich spinels contain as little as 2 mole per cent magnetite, others as much as $\mathbf{3}$ per cent gahnite. Exhumed spinel inclusions and small spinel grains in cordierite have intermediate $M$ values.

Spinels from Cod6A are richer in $\mathrm{Zn}$ and have compositions close to $\mathrm{Sp}_{40} \mathrm{Hc}_{32} \mathrm{Mt}_{2} \mathrm{Gahn}_{6}$.

Staurolite. Staurolite analyses have been calculated to 48 oxygens and 4 hydrogens (i.e. to 46 oxygens in the anhydrous state) as suggested by Griffen et al. (1982) assuming all iron to 

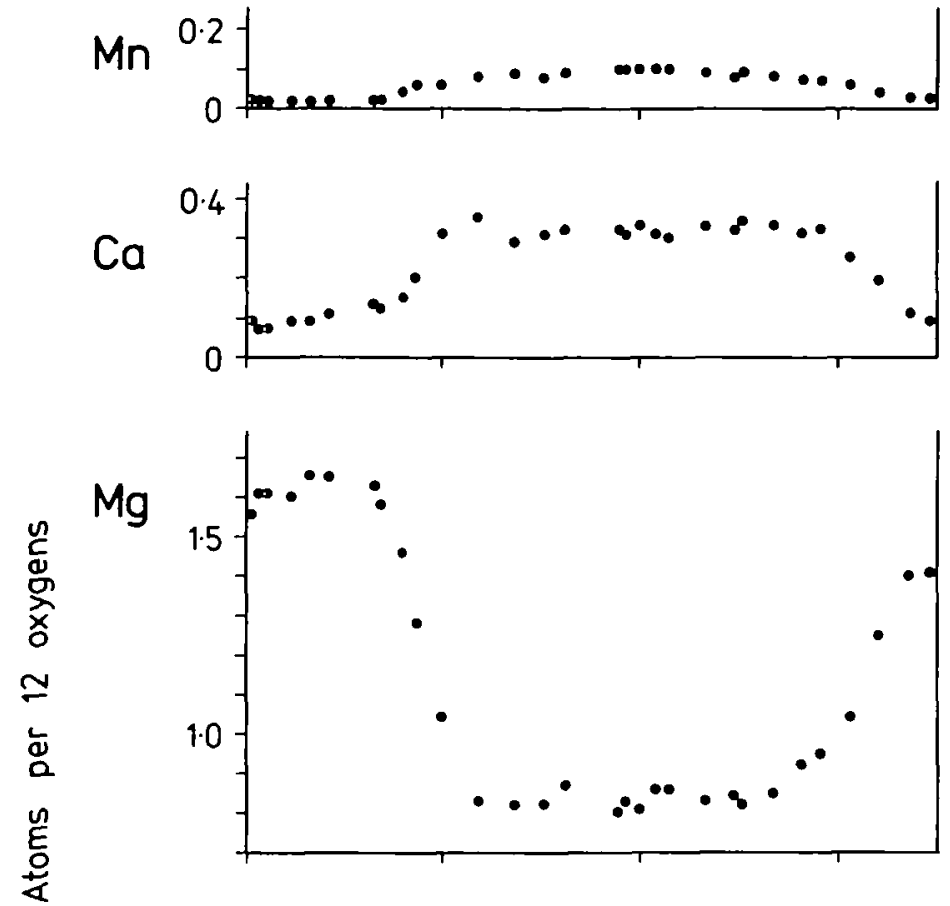

$\mathrm{Fe}$
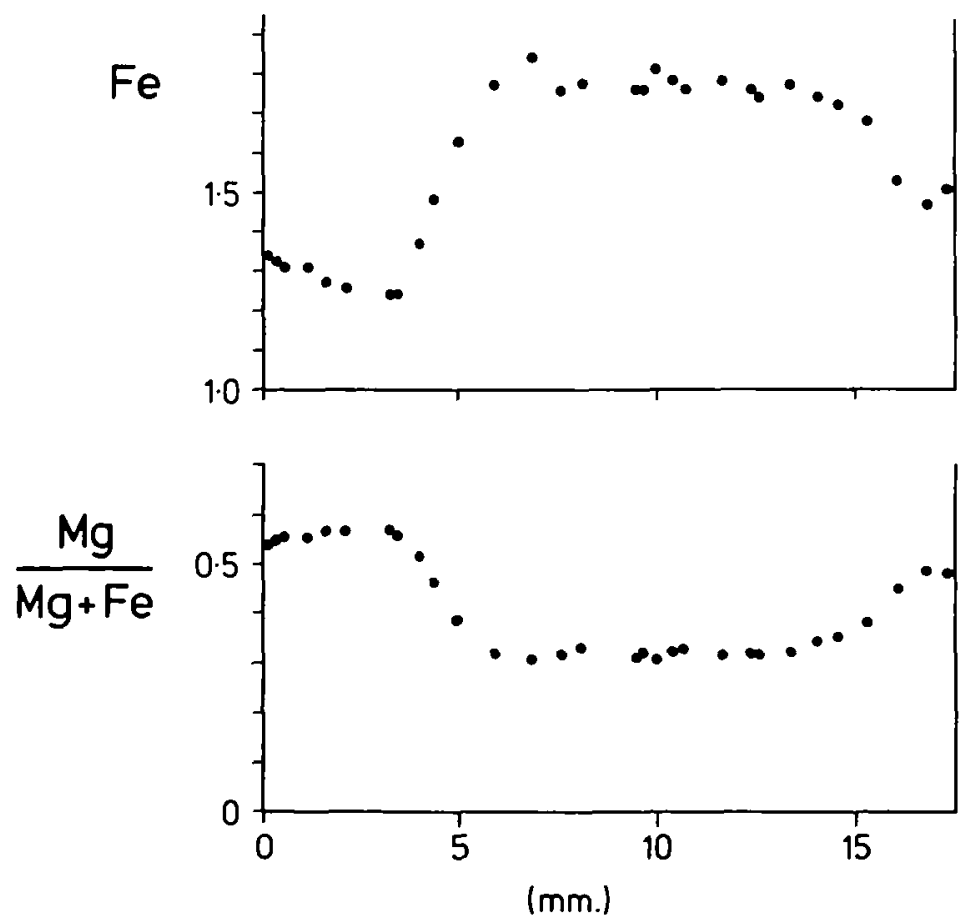

Fio. 13. Zoning profile of a garnet porphyroblast in TS 100 .

be $\mathrm{Fe}^{2+}$. Compared with normal staurolites, those studied here are unusual in that they are very aluminous (up to $19.1 \mathrm{Al}$ atoms per 46 oxygens), and correspondingly poor in $\mathrm{Si}$ (as few as 6.5 atoms) without being abnormally poor in $\mathrm{Mg}+\mathrm{Fe}$ (4.0 to 4.2 atoms). The Si contents 
A

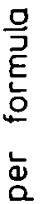

$\stackrel{n}{E}$
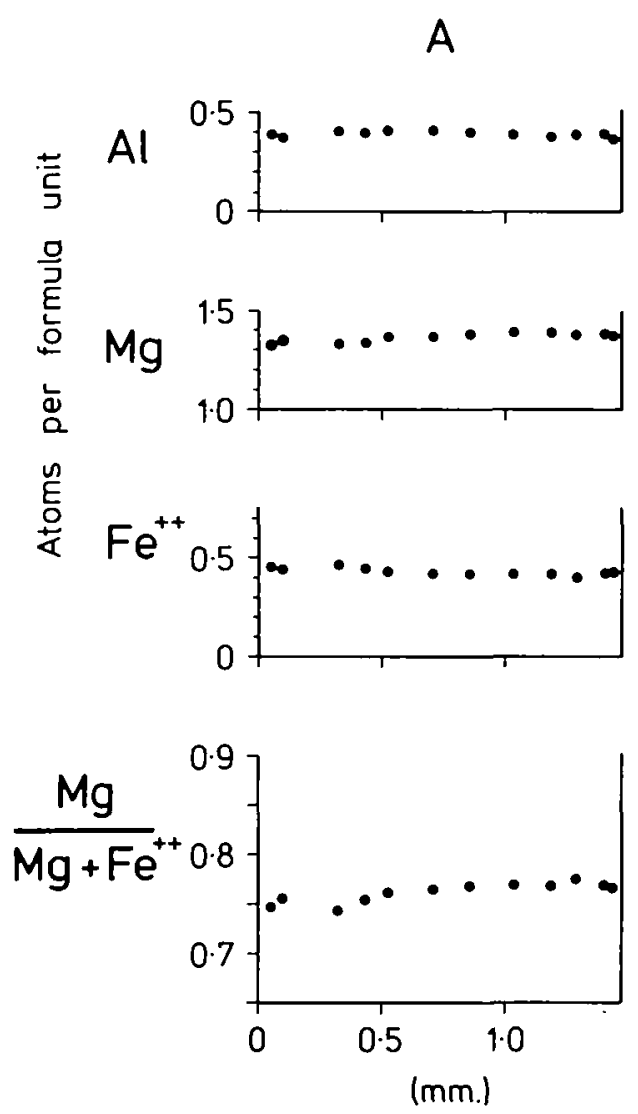

B $\quad$ C
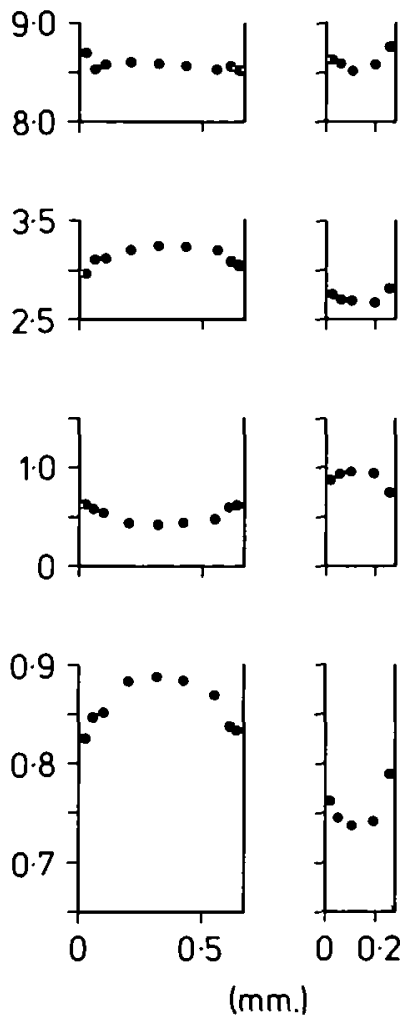

FIG. 14. Zoning profiles of orthopyroxene and sapphirines in AL20B. (a) matrix prismatic orthopyroxene. (b) matrix prismatic sapphirine. (c) euhedral sapphirine in sa + biot $+\mathrm{qz}$ inclusion shown in Fig. $6 d$.

are lower than any yet reported (see Ribbe, 1982, p. 178). It is not clear how much structurally bound water these staurolites contain; high anhydrous oxide weight per cent totals suggest very low water contents, but high cation totals are reasonably consistent with the theoretical value of $2 \mathrm{H}_{2} \mathrm{O}$ per formula unit. Clearly, water and $\mathrm{Fe}^{3+}$ contents must be known before the relative importance of $\mathrm{Si}=4 \mathrm{H}$ (Richardson, 1968), $\mathrm{Al}=\mathrm{Fe}^{3+}$, and Tschermak substitutions can be ascertained.

Most staurolite inclusions in garnet cores have $M$ values of $\sim 0 \cdot 34$, but values of up to 0.43 have been measured on inclusions in garnet outer cores. Minor amounts of $\mathrm{Ti}, \mathrm{Co}$, and $\mathrm{Mn}$ are generally present but no $\mathrm{Zn}$ or $\mathrm{Cr}$ could be detected.

Sillimanite and corundum. The only impurity detected was iron $\left(0.5-0.7\right.$ per cent $\mathrm{Fe}_{2} \mathrm{O}_{3}$ in sillimanite, c. 1.5 per cent in corundum).

Ilmenite. Ilmenite inclusions in garnet are rich in $\mathrm{Mg}$ and have compositions close to $\mathrm{I}_{1} \mathrm{~m}_{83}$ Geik $_{14} \mathrm{Hem}_{3}$.

$K$-feldspar. Integrated TS100 microperthite compositions range from $\operatorname{Or}_{81} \mathrm{Ab}_{18} \mathrm{An} \mathrm{n}_{1}$ to $\mathrm{Or}_{84} \mathrm{Ab}_{15} \mathrm{An}_{1}$.

Plagioclase. Matrix plagioclases were found to have fairly uniform compositions $\left(\mathrm{An}_{48}-\mathrm{An}_{34}\right.$ in TS100; $\mathrm{An}_{38}-\mathrm{An}_{40}$ in AL20B). Plagioclases in AL19 and Cod6A range in composition from $A n_{87}$ to $A n_{90}$ and from $A n_{29}$ to $A n_{30}$, respectively. 


\section{INTERPRETATION OF MINERAL TEXTURES}

In this section, mineral textures and compositions are used to construct a sequence of metamorphic reactions describing the mineralogical evolution of the sapphirine-granulites (the approach of Thompson et al., 1977). Fortunately, many of the early assemblages in the sapphirine-granulites appear to be partially preserved. Nevertheless, because early-formed minerals were necessarily consumed in the crystallization of subsequent assemblages, the early assemblages are probably incomplete. There is therefore considerable uncertainty in the interpretation of the early stages of the metamorphic history detailed below.

\section{(1) Staurolite stage}

The earliest recognizable stage in the mineralogical history of the sapphirine-granulites is represented by the garnet cores and their inclusions of quartz, biotite, staurolite, and spinel. Since many of the inclusions are monomineralic, they are likely to be primary (i.e. their assemblages have not changed since they were enclosed by garnet) rather than secondary (in which present mineral assemblages developed through reaction between primary inclusion minerals and enclosing garnet after entrapment).

The assemblage $\mathrm{gt}+\mathrm{st}+\mathrm{biot}+\mathrm{qz}$ is common in amphibolite facies metapelites and is normally accompanied by muscovite. The assemblage $\mathrm{K}$-feldspar + sillimanite takes the place of muscovite + quartz in the matrix of the sapphirine-granulites, but there is no evidence that music $+\mathrm{qz}$ was not once stable. The relatively low $M$ values of garnet core and staurolites (compared to the $M$ values of the bulk rock and the matrix minerals) are consistent with these rocks having once been comparatively Fe-rich staurolite zone metapelites. The composition of staurolite and adjacent parts of garnet cores may have been slightly modified after formation during the granulite facies metamorphism (as indicated by the unusual high $M$ values of staurolite). Textural evidence discussed earlier suggests that kyanite may have been the stable $\mathrm{Al}_{2} \mathrm{SiO}_{5}$ polymorph early in the rock's history. Rare relicts of kyanite were reported from two metapelitic gneisses in the Gruf Complex (see Bucher-Nurminen \& Droop, 1983). The presence of isolated spinel inclusions in garnet cores implies that spinel coexisted with matrix phases during garnet growth. Partial rims of spinel around staurolite (Fig. $6 f$ ) argue that spinel grew from a reaction involving staurolite. No composite $\mathrm{Qz}+$ Stau inclusions were found in any of the garnet cores. The upper stability limit of $\mathrm{Qz}+\mathrm{Stau}$ is given by the reaction:

$$
6 \mathrm{St}+11 \mathrm{Qz} \rightarrow 4 \mathrm{Alm}+23 \mathrm{Ky}+3 \mathrm{H}_{2} \mathrm{O}
$$

The textures suggest that staurolite in qz-saturated portions of the rocks was removed by some mechanism other than reaction 4 , because of the absence of abundant kyanite (sillimanite) in garnet cores. Because of the incomplete preservation of the early assemblages, many kyanite-absent reactions consistent with the textural observations and the modal distribution of inclusion minerals in garnet core areas (Table 2) can be formulated but their significance would be difficult to prove.

The close association of spinel and quartz in garnet cores (Fig. 2) is puzzling. This assemblage is known only from high temperature granulite terrains where sillimanite is the stable $\mathrm{Al}_{2} \mathrm{SiO}_{3}$ polymorph (Ellis et al., 1980; Vielzeuf, 1983; D. J. Waters, pers. comm.). In view of this it seems unlikely that spinel and quartz could have coexisted at an early stage in the Codera rocks, especially as they have not been found in direct contact. The spinel may be a breakdown product of staurolite in localized silica-deficient parts of the rock by the reaction:

$$
10 \mathrm{St} \rightarrow 3 \mathrm{Alm}+11 \mathrm{Hc}+31 \mathrm{Ky}+5 \mathrm{H}_{2} \mathrm{O}
$$


The stable matrix assemblage by the end of the staurolite stage may have been $\mathrm{Gt}+\mathrm{Ky}+$ Biot + Plag $+\mathrm{Qz} / \mathrm{Sp}$ (+ Musc ?). This assemblage follows from observed single phase inclusions in garnet core areas. The persistence of peraluminous staurolite in the garnet cores implies on the other hand that the upper thermal stability of staurolite was never exceeded during the metamorphic history of the rock.

\section{(2) Pyrope stage}

The next stage in the metamorphic history began with a dramatic increase in garnet $M$ value from 0.3 to 0.6 (Fig. 13) and a corresponding increase in $M$ values of ferromagnesian minerals included in garnet. This dramatic increase of the $\mathrm{Mg} /(\mathrm{Mg}+\mathrm{Fe})$ ratio in the minerals reflects a substantial increase in bulk rock $M$ value.

The evidence for this is as follows:

(a) It is impossible to generate the present bulk rock composition by mixing the minerals of the early staurolite stage assemblage $\mathrm{Gt}+\mathrm{St}+\mathrm{Biot}+\mathrm{Ky}+\mathrm{Qz}+\mathrm{Musc}+$ Plag (see above) without obtaining large negative modal coefficients (Table 6, column 1). This calculation assumes that the relevant mineral compositions have not changed significantly since then.

(b) The deduced early staurolite stage mineralogy as given above may be incomplete or incorrect, due to the limited information on the early stages. As a potential $\mathrm{Mg}$-rich precursor mineral, chlorite seems a good candidate, although there is no positive evidence for its former presence in the early staurolite stage assemblage. However, the inclusion mineralogy in garnet core areas, textural evidence (see above) and the occurrence of relict kyanite in the Gruf Complex are positive evidence that in terms of an AFM projection the minerals garnet, staurolite, biotite and kyanite were present at the early staurolite stage. Chlorite nevertheless could have been present in the amphibolite facies prograde assemblage, in which case five

\section{TA B LE 6}

Modal calculations. The columns list the modal proportions required to generate the present observed whole-rock composition (taken from Barker, 1964) from given assemblages of minerals of known composition appropriate to each stage

\begin{tabular}{|c|c|c|c|c|c|c|c|}
\hline \multirow[b]{2}{*}{ Stage } & \multicolumn{7}{|c|}{ Modal proportions } \\
\hline & $\begin{array}{c}I \\
\text { Staurolite } \\
\text { stage }\end{array}$ & $\begin{array}{c}2 \\
\text { Pyrope } \\
\text { stage }\end{array}$ & $\begin{array}{c}3 \\
\text { Pyrope } \\
\text { stage }\end{array}$ & $\begin{array}{c}4 \\
\text { Sapphirine } \\
\text { stage }\end{array}$ & $\begin{array}{c}5 \\
\text { Cordiertte } \\
\text { stage }\end{array}$ & $\begin{array}{c}6 \\
\text { Symplectite } \\
\text { stage }\end{array}$ & $\begin{array}{c}7 \\
\text { Symplectite } \\
\text { stage }\end{array}$ \\
\hline Quartz & $-15 \cdot 40$ & -0.71 & & & & & \\
\hline Sillimanite & 55.23 & 0.70 & 0.21 & & & & \\
\hline Staurolite & $-68 \cdot 80$ & & & & & & \\
\hline Garnet $\left(\mathbf{P y}_{30}\right)$ & 31.28 & & & & & & \\
\hline Biotite & 0.32 & 0.32 & 0.32 & 0.05 & 0.44 & 0.19 & 0.32 \\
\hline Plagioclase & 0.04 & 0.04 & 0.04 & 0.02 & 0.04 & 0.03 & 0.04 \\
\hline Spinel & & $-1 \cdot 14$ & 0.05 & & & & \\
\hline Garnet $\left(P y_{45}\right)$ & & 1.83 & -0.17 & & & & \\
\hline Orthopyroxęne & & & 0.54 & 0.55 & 0.09 & 0.39 & 0.23 \\
\hline Sapphirine & & & & 0.27 & & 0.17 & 0.08 \\
\hline Cordierite & & & & & 0.32 & 0.12 & 0.22 \\
\hline K-feldspar & & & & $0 \cdot 18$ & -0.08 & 0.09 & \\
\hline Garnet (Pyss) & & & & -0.11 & 0.19 & & $0 \cdot 10$ \\
\hline$\sum \mid$ mode $\mid$ & 171 & $4 \cdot 74$ & 1.33 & $1 \cdot 18$ & $1 \cdot 16$ & 0.99 & 0.99 \\
\hline
\end{tabular}


AFM phases would have coexisted. The bulk rock composition of the early staurolite stage rock must have had a $M$ value lower than that defined by the tie-lines between chlorite and kyanite (or staurolite) and chlorite and biotite. $M$ values of garnet core staurolite, biotite and garnet are $0.32,0.61$ and 0.32 , respectively. Even allowing the hypothetical chlorite to have had a slightly higher $M$ value than the coexisting biotite (Thompson, 1976) the present bulk rock $M$ value of 0.76 is still outside accessible chemical space if modal abundance requirements are to be met.

The inferred change in bulk rock composition between the staurolite and pyrope stages was probably a consequence of partial melting. This is supported by the following evidence:

(a) Migmatitic gneisses and granites form the bulk of the Gruf Complex showing that the unit reached conditions of partial melting during its geological history.

(b) In the mixed rock Cod6A, the sapphirine + biotite mafic lenses have a higher bulk $M$ value than the enclosing leucocratic $\mathrm{Qz}+\mathrm{Ksp}+\mathrm{Plag}+\mathrm{Gt}+\mathrm{Opx}+\mathrm{Biot}-$ rock. The migmatitic nature of this rock can be explained if both leucosome and melanosome resulted from the partial melting of a homogeneous precursor (the comparatively Fe-rich leucocratic rock representing the melt, and the $\mathrm{Mg}$-rich mafic lenses the restite).

(c) The granulites certainly underwent prograde metamorphism at high grade and ultimately attained temperatures of about $800^{\circ} \mathrm{C}$ (Fig. 16), well within the field of wet melting of muscovite- and quartz-bearing pelites (Storre \& Karotke, 1972).

(d) The mass-balance calculations of McRae \& Nesbitt (1980) show that partial melting of a pelite is likely to result in increasing the $M$ value of the refractory residue relative to the protolith.

(e) A wide range of bulk chemical compositions is represented by the metapelitic rocks of the Gruf Complex (Bucher-Nurminen \& Droop, 1983). Most of these rocks show features of partial melting (e.g. cross-cutting veinlets or irregular patches of feldspar + quartz leucosome). The sapphirine-granulites are likely to represent restites left after extraction of a very high proportion of leucosome. Metapelitic gneisses with lower bulk rock $M$ values have equilibrated under the conditions of the cordierite or symplectite stages (see below), (Bucher-Nurminen \& Droop, 1983) and have 'lost their memory' of their granulite facies past. The higher the bulk rock $M$ value of the gneisses (corresponding to higher degrees of extracted melt) the better is the preservation of granulite facies assemblages.

The actual melting reactions that affected the granulite precursors are not known, but it can be assumed that the assemblage muscovite + quartz was removed during this process. A major textural effect of melting was to crystallize garnet. The growth of garnet during partial melting can be expressed by the schematic reaction:

$$
\text { Biot }+\mathrm{H}_{2} \mathrm{O}+\text { other minerals } \rightarrow \mathrm{Gt}+\text { melt }
$$

The garnet and liquid produced would have been more Fe-rich than the biotite. Thus, if melting was fractional; $M$ values of remaining garnet (and biotite) would have increased, as observed in the zoning profile.

Melting reactions consume water. In a rock system closed or partially closed to water, the assemblages Musc $+\mathbf{K y}+\mathrm{Qz}+$ melt and $\mathrm{Gt}+\mathrm{Ky}+$ Biot $+\mathrm{Qz}+$ melt can buffer the water contents of coexisting vapours to progressively lower values with increasing temperature. In such a system, therefore, reaction 6 (and other $\mathrm{H}_{2} \mathrm{O}$ consuming melting reactions) are likely to be continuous (Powell, 1983).

Further melting resulted in an abrupt 'flattening-out' of the garnet $M$ value zoning profile (Fig. 13). The reason for this may have been a change from fractional to equilibrium melting. The first appearance of K-feldspar inclusions coincides with this point in the garnet profile. Textural evidence suggests that biotite melting reactions failed to go to completion. The 
assemblage biotite and quartz persists in the rock matrix and has not been completely removed from the rock.

By the end of the pyrope stage, the garnets had grown very large (about $3 \mathrm{~cm}$ diameter). Primary kyanite, spinel and spinel + kyanite inclusions were probably trapped in pyrope rims along with the observed biotite, quartz, rutile and ilmenite. Observed spinel + corundum and corundum $+\mathrm{Al}_{2} \mathrm{SiO}$, inclusions may have developed from them by the reaction:

$$
3 \mathrm{Sp}+3 \mathrm{Ky} \rightarrow \mathrm{Gt}+5 \mathrm{Crm}
$$

which also could have resulted in corundum growth in silica-deficient parts of the rock matrix. The resultant stable matrix sub-assemblages were: (i) $\mathrm{Gt}+\mathrm{Ky}+\mathrm{Qz}+\mathrm{Biot}+\mathrm{Ksp}+\mathrm{Plag}$ (silica-saturated), (ii) $\mathrm{Gt}+\mathrm{Ky} / \mathrm{Sp}+\mathrm{Crm}+\mathrm{Biot}+\mathrm{Ksp}+$ Plag (silica-deficient). Parts of the feldspar \pm quartz in these assemblages presumably occurred as a melt phase.

\section{(3) Prismatic sapphirine stage}

Further rise in temperature resulted in the crystallization of prismatic sapphirine in both the rock matrix and in composite inclusions in garnet rims. One of the following reactions is likely to have been largely responsible for the formation of sapphirine:

$$
\begin{gathered}
2 \mathrm{Biot}+6 \mathrm{Ky} \rightarrow 3 \mathrm{Sa}+3 \mathrm{Qz}+2 \mathrm{Ksp}+2 \mathrm{H}_{2} \mathrm{O} \\
\mathrm{Biot}+\mathrm{Ky}+\mathrm{H}_{2} \mathrm{O} \rightarrow \mathrm{Sa}+\mathrm{Qz}+\text { Melt }
\end{gathered}
$$

The textural evidence for this is the spatial dissociation of coarse biotite and $\mathrm{Al}_{2} \mathrm{SiO}_{3}$ in the rock matrix. Reaction 8 a could also explain the appearance of composite sapphirine + quartz inclusions in garnet (Figs. $6 a, 6 d$ ) by the decomposition of primary biotite + kyanite inclusions.

Textures such as composite sapphirine + spinel + corundum inclusions in garnet (Fig. 6e) and closely associated corundum and spinel inclusions within prismatic sapphirine indicate that in silica-deficient parts of the rock, sapphirine was produced by the reaction:

$$
\mathrm{Gt}+3 \mathrm{Sp}+2 \mathrm{Crm} \rightarrow 3 \mathrm{Sa}
$$

Reaction 9 resulted in the conversion of most of the matrix spinel to sapphirine, with some sapphirine preserving unreacted spinel relicts as inclusions (Fig. 5a), and the conversion of some spinel + corundum inclusions in garnet to secondary sapphirine + spinel inclusions.

The presence of high-alumina orthopyroxene inclusions in prismatic sapphirine suggests that orthopyroxene began to crystallize during sapphirine growth. Some of the orthopyroxene could have been produced by continuous melting reactions such as

$$
\mathrm{Biot}+\mathrm{Qz} \rightarrow \mathrm{Opx}+\mathrm{Ksp}+\text { melt }
$$

but textures such as (i) 'islands' of relict garnet in prismatic orthopyroxene (Fig. $4 d$ ), and (ii) composite orthopyroxene + sapphirine inclusions in, and apparently replacing, garnet rims (Fig. $6 c$ ) indicate that some of the high-alumina prismatic orthopyroxene and sapphirine was produced by one of the following continuous garnet resorption reactions:

$$
6 \mathrm{Gt} \rightarrow 7 \mathrm{Opx}+2 \mathrm{Sa}+2 \mathrm{Ky}
$$

(Fig. 15) and

$$
2 \mathrm{Gt} \rightarrow 2 \mathrm{Opx}+\mathrm{Sa}+\mathrm{Qz}
$$

By the end of the prismatic sapphirine stage, the rocks had acquired much of the coarse-grained granulose texture visible today. Large $(2 \cdot 5-3 \mathrm{~cm}$ diameter) garnets (already 
showing signs of resorption) were embedded in a matrix of kyanite, prismatic sapphirine, prismatic orthopyroxene, biotite, quartz, K-feldspar and plagioclase. The stable matrix sub-assemblage in $\mathrm{Al}_{2} \mathrm{SiO}_{5}$-deficient areas was:

$$
\mathrm{Gt}+\mathrm{Qz}+\mathrm{Sa}+\mathrm{Opx}+\mathrm{Biot}+\mathrm{Ksp}+\mathrm{Plag}
$$

The composite inclusion of Fig. $6 a$ provides direct evidence for this sub-assemblage. The close association of prismatic orthopyroxene, prismatic sapphirine, garnet and sillimanite (after kyanite) in Fig. $4 a$ suggests that in $\mathrm{Al}_{2} \mathrm{SiO}_{5}$-saturated areas (common only in TS100) the stable sub-assemblage at this stage was:

$$
\mathrm{Gt}+\mathrm{Ky}+\mathrm{Sa}+\mathrm{Opx}+\mathrm{Ksp}+\mathrm{Plag}+\mathrm{Qz}
$$

Modal calculations (Table 6, column 4) indicate that the sapphirine-granulites had already achieved $\mathrm{Mg}, \mathrm{Al}$-rich bulk compositions close to present values by the end of the prismatic sapphirine stage, and that fractional melting had ceased.

\section{(4) Cordierite stage}

The large grain size of pyrope stage and prismatic sapphirine stage reaction products and the extent to which many of the reactions went to completion suggest that temperature was rising over this period. In subsequent stages, however, reaction products became progressively finer-grained (tending to form reaction rims, coronas, and ultimately symplectites) and many reactions failed to go to completion. These features imply a reduction in the scale of equilibrium, and require either falling temperature or a progressive 'drying-out' of the rocks or both.
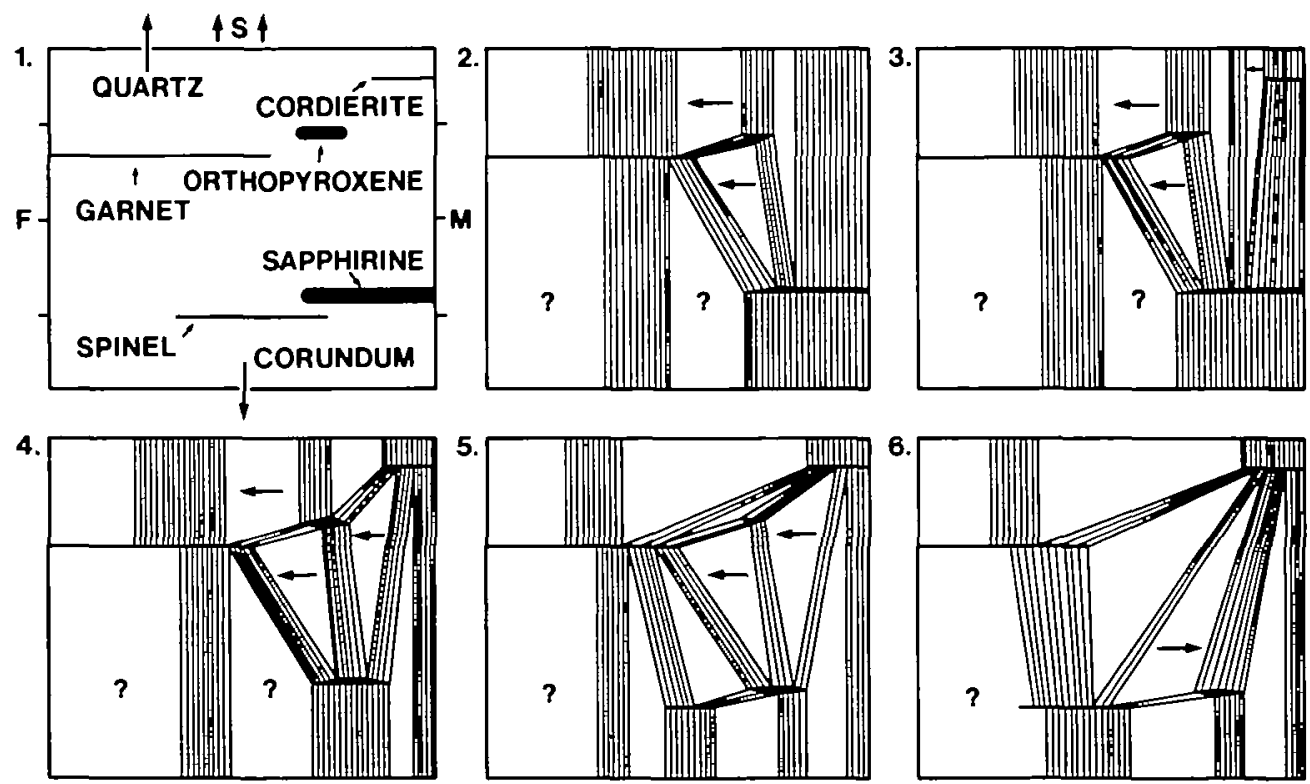

FIG. 15. Sequence of schematic 'opx-spinel' projections (as in Fig. 12) from $\mathrm{Al}_{2} \mathrm{SiO}_{3}$ (kyanite, 2; sillimanite, 3-6) summarizing the later part of the reaction history of the Bresciadega sapphirine-granulites. Migration directions of 3-phase triangles are only shown for reactions supported by textural evidence. 1. Chemographic relationships; 2 . Prismatic sapphirine stage (late); 3. Cordierite stage (early); 4. Cordierite stage (late); 5. Symplectite stage (early); 6. Symplectite stage (late). 
The composite high-alumina orthopyroxene + sillimanite inclusions in garnet rims (Figs. 3, $6 b$ ) probably developed during this stage of initial temperature drop by reaction of primary quartz inclusions with pyrope-rich garnet host:

$$
2 \mathrm{Gt}+2 \mathrm{Qz} \rightarrow 3 \mathrm{Opx}+2 \mathrm{Al}_{2} \mathrm{SiO}_{3}
$$

Reaction 13 is one explanation for the comparative rarity of quartz inclusions in pyropic rims of the garnets. The preservation of primary quartz inclusions in garnet cores is due to the low pyrope activity (hence high value of $\mathrm{K}_{13}$ ) for garnet cores compared with rims.

As sillimanite seems to have been the stable $\mathrm{Al}_{2} \mathrm{SiO}_{5}$ polymorph during reaction 13 , the pseudomorphing of large kyanite crystals by aggregates of prismatic sillimanite probably also took place at this time:

$$
\mathrm{Ky} \rightarrow \text { Sill }
$$

The broad reaction rims of cordierite between prismatic sapphirine and quartz (Fig. $5 d$ ) formed during this stage by the reaction:

$$
\mathrm{Sa}+5 \mathrm{Qz} \rightarrow \text { Cord }
$$

In the $\mathrm{MgO}-\mathrm{Al}_{2} \mathrm{O}_{3}-\mathrm{SiO}_{2}$ system, the equilibrium has $\mathrm{d} P / \mathrm{d} T \approx 0$ (Newton, 1972), suggesting that pressure was decreasing at this stage.

Because $\mathrm{Mg}$-sapphirine was preferentially dissolved during reaction 15, the remaining sapphirine became richer in iron (Fig. 15). This resulted in the development of the characteristic dark Fe-rich rims of the large matrix sapphirines (Fig. 14B) and explains the absence of such rims in sapphirine grains still contacting quartz.

Localized reaction rims of low alumina orthopyroxene formed between quartz and coarse biotite (Fig. $5 c$ ) at this stage by the reaction:

$$
2 \mathrm{Bi}+6 \mathrm{Qz} \rightarrow 3 \mathrm{Opx}+\mathrm{Ksp}+2 \mathrm{H}_{2} \mathrm{O}
$$

In contrast to the prograde melting reaction 10 above, Opx rims formed by reaction 16 resulted from locally fluctuating $\mathrm{H}_{2} \mathrm{O}$ activities during the inferred $\mathrm{P}-\mathrm{T}$ drop.

\section{(5) Symplectite stage}

Continued falling pressure and temperature led to the development of localized symplectitic coronas by cordierite producing reactions which consumed garnet, prismatic orthopyroxene and sillimanite. In general, these reactions did not involve quartz because initial cordierite crystallization by reaction 15 effectively desilicated the bulk of the rock matrix.

The sapphirine + cordierite symplectites around sillimanite aggregates (Figs. 3, 4a) developed as the result of the reaction:

$$
4 \mathrm{Opx}+8 \mathrm{Sill} \rightarrow \mathrm{Sa}+3 \text { Cord (see also Schreyer, 1970) }
$$

Several reactions were involved in garnet breakdown. The fine-grained orthopyroxene + sapphirine symplectites (Fig. $4 b$ ) have an integrated composition $(\mathrm{MgO}+$ $\mathrm{FeO})_{46}\left(\mathrm{Al}_{2} \mathrm{O}_{3}\right)_{14}\left(\mathrm{SiO}_{2}\right)_{40}$ very close to pyralspite garnet (Fig. 7), and were probably formed, therefore, by near-isochemical decomposition of garnet:

$$
8 \mathrm{Gt} \rightarrow 8 \mathrm{Opx}+3 \mathrm{Sa}+\mathrm{Cord}
$$

The fan-like shapes of these intergrowths imply that reaction 18 became progressively less important with respect to the reaction producing the abundant orthopyroxene + cordierite 
symplectites (Figs. 3, 4a, 4b). This common type of intergrowth is usually explained by the reaction:

$$
2 \mathrm{Gt}+3 \mathrm{Qz} \rightarrow 2 \mathrm{Opx}+\text { Cord }
$$

(e.g. Schreyer \& Abraham, 1978) but the rarity of quartz in the Codera rocks by this stage makes reaction 19 very unlikely. A more plausible reaction would be:

$$
4 \mathrm{Gt}+2 \mathrm{Ksp}+2 \mathrm{H}_{2} \mathrm{O} \rightarrow \mathrm{Opx}+2 \mathrm{Cord}+2 \mathrm{Bi}
$$

which would also explain the biotite coronas around garnets (Fig. 2). The biotite rims fringing prismatic orthopyroxene (Fig. $5 b$ ) could also have developed at this stage by the reverse of reaction 16 (again as the result of local variations in the $\mathrm{H}_{2} \mathrm{O}$ activity).

Towards the end of the symplectite stage, spinel took the place of sapphirine in symplectite-producing reactions still in progress, indicating that sapphirine had become unstable with respect to spinel + cordierite:

$$
5 \mathrm{Sa} \rightarrow 8 \mathrm{Sp}+\text { Cord }
$$

For example, the textures in Fig. $4 b$ show that reaction 18 ultimately gave way to:

$$
5 \mathrm{Gt} \rightarrow 5 \mathrm{Opx}+3 \mathrm{Sp}+\text { Cord }
$$

The end of the symplectite stage marks the end of the reaction history for most of the rocks studied. Total cessation of reaction at this point was probably caused by hydration reactions (such as 16 and 20) using up the remaining $\mathrm{H}_{2} \mathrm{O}$ (which may have been stored partially in cordierite).

\section{(6) Retrograde hydration}

A few samples show evidence of the following retrogressive hydration reactions, either in localized patches, adjacent to late fractures (e.g. AL21, TS 100) or pervasively (e.g. AL41):

$$
\begin{aligned}
& \mathrm{Sill}+\mathrm{Ksp}+\mathrm{H}_{2} \mathrm{O} \rightarrow \mathrm{Musc}+\mathrm{Qz} \\
& 7 \mathrm{Opx}+2 \mathrm{Qz}+2 \mathrm{H}_{2} \mathrm{O} \rightarrow 2 \text { Anth }
\end{aligned}
$$

In AL41, symplectitic orthopyroxene was affected by reaction 24 , implying that the influx of $\mathrm{H}_{2} \mathrm{O}$ responsible occurred after the symplectite stage.

\section{CONDITIONS OF METAMORPHISM}

In this section, an attempt is made to quantify the $P-T$ evolution of the sapphirine-granulites. If it can be assumed that the mineral sub-assemblage assigned to a particular evolutionary stage on textural grounds was in chemical equilibrium at that stage, and that individual mineral compositions were not significantly altered by subsequent re-equilibration, then the physical conditions under which each sub-assemblage equilibrated may be estimated using geothermometers and geobarometers based on equilibrium thermodynamics. However, the compositions of some minerals have obviously changed since their formation (e.g. staurolite, spinel included in garnet). Equilibria involving such minerals consequently result in minimum or maximum $P-T$ estimates for a given stage depending on the reaction stoichiometry. An extreme case of late equilibration of mineral chemistry was found in biotite inclusions in garnet (see below). 


\section{Thermodynamic calculations-methods}

(i) Equilibria in the $\mathrm{MgO}-\mathrm{Al}_{2} \mathrm{O}_{3}-\mathrm{SiO}_{2}$ system. Equilibria among pyrope, enstatite, sapphirine, sillimanite, kyanite, cordierite, quartz, spinel and corundum were calculated using the approach of Kleppa \& Newton (1975), which is based on high-temperature $(1000 \mathrm{~K})$ oxide-melt solution calorimetry. If temperatures of interest are fairly close to $1000 \mathrm{~K}$, (as they are likely to be in this study), the position of a solid-solid equilibrium may be calculated from the equation:

$$
0=\Delta H_{(\mathrm{r}) 1,1000}-T \Delta S_{(\mathrm{r}) 1000}+(P-1) \Delta V_{(\mathrm{r}) 1,1000}+R T \ln K
$$

where $\Delta H_{(\mathrm{r}) 1,1000}, \Delta S_{(\mathrm{r}) 1000}$ and $\Delta V_{(\mathrm{r}) 1,1000}$ denote the enthalpy, entropy and volume change of a given reaction at $1 \mathrm{bar}$ and $1000 \mathrm{~K} . R$ stands for the gas constant, $P$ for the pressure of interest, $T$ for the temperature in Kelvin and $\ln K$ for the natural logarithm of the equilibrium constant at $P$ and $T$. The data set used with this equation is essentially that of Harris \& Holland (1984), with the addition of data for disordered $2: 2: 1$ sapphirine. The entropy and molar volume of sapphirine at $1000 \mathrm{~K}\left(664.2 \mathrm{~J} \mathrm{~K}^{-1} \mathrm{~mol}^{-1}\right.$ and $100.63 \mathrm{~cm}^{3}$, respectively) were taken from Kleppa \& Newton (1975). The enthalpy of formation of sapphirine from the oxides at $1000 \mathrm{~K}\left(-4.41 \mathrm{~kJ} \mathrm{~mol}^{-1}\right)$ was adjusted to make the data set consistent with the experimental reversals of Newton (1972) for equilibrium 9. Mineral compressibilities have been ignored.

Unfortunately, the data set is not entirely consistent with all experimentally reversed equilibria. In particular, the data cannot be made consistent with the experimental reversals of Hensen \& Essene (1971) and Hensen (1972) for equilibrium 13, the reversals of Ackermand et al. (1975) for equilibrium 15, or the reversals of Chatterjee \& Schreyer (1972) for the equilibrium:

$$
\mathrm{En}+2 \mathrm{Sill}=\mathrm{Sa}+3 \mathrm{Qz}
$$

(even allowing for $\mathrm{Al}$ in enstatite) without greatly modifying enthalpies and entropies of several phases. Equilibria 13,15 and 25 all have very small volume changes and are thus liable to large errors in both slope and position. In applying the data to the sapphirinegranulites the greatest faith is placed on equilibria with large volume changes. The minimum error on each geobarometer is $\pm 2 \mathrm{~kb}$.

The data derived for sapphirine from experimentally studied equilibria necessarily refer to disordered sapphirine (Kiseleva, 1976). In applying the data to the Gruf rocks with natural ordered sapphirine serious uncertainties may therefore be introduced with respect to the positions of solid-solid reactions involving sapphirine. This may explain the apparent discrepancy of the assemblage sapphirine + kyanite deduced from the textures with experimentally derived topologies in this system (e.g. Newton, 1972).

In calculating activites of end-member components in minerals ideal mixing was assumed for all solutions. For orthopyroxene and cordierite the solution models are as follows:

$$
\begin{array}{lc}
\text { Enstatite: } & a_{\mathrm{EN}}^{\mathrm{OPX}}=X_{\mathrm{Mg}}^{\mathrm{M} 1} \cdot X_{\mathrm{Mg}}^{\mathrm{M}_{2}} \\
\text { Cordierite: } & a_{\mathrm{CORD}}^{\mathrm{CORD}}=\left(X_{\mathrm{Mg}}\right)^{2} \cdot\left(1-X_{\mathrm{H}_{2} \mathrm{O}}\right),
\end{array}
$$

where $X_{\mathrm{H}_{2} \mathrm{O}}$ represents the number of moles of $\mathrm{H}_{2} \mathrm{O}$ per mole anhydrous cordierite. $X_{\mathrm{H}_{2} \mathrm{O}}$ has been taken as 0.262 throughout.

(ii) Equilibria in the system $\mathrm{FeO}-\mathrm{Al}_{2} \mathrm{O}_{3}-\mathrm{SiO}_{2}-\mathrm{H}_{2} \mathrm{O}$. Equilibria among almandine, Fe-cordierite, hercynite, corundum, quartz, sillimanite, kyanite, staurolite and chloritoid were calculated using the program SUPCRT and a modified form of Helgeson's data set (Helgeson et al., 1978). Standard state thermodynamic data for quartz, $\mathrm{Al}_{2} \mathrm{SiO}_{3}$ polymorphs and 
TABLE 7

Thermodynamic data for FASH phases, used in conjunction with the data set of Helgeson et al., 1978

\begin{tabular}{llccc}
\hline Mineral & \multicolumn{1}{c}{ Formula } & $\begin{array}{c}\Delta_{\mathrm{f}} \mathrm{H}^{0} \\
(\mathrm{~J} \mathrm{~mol}\end{array}$ & $\begin{array}{c}\mathrm{S}^{0} \\
\left(\mathrm{~J} \mathrm{~mol}^{\left.-1 / K^{-1}\right)}\right.\end{array}$ & $\begin{array}{c}V^{*} \\
\left(\mathrm{~cm}^{3}\right)\end{array}$ \\
\hline Almandine & $\mathrm{Fe}_{3} \mathrm{Al}_{2} \mathrm{Si}_{3} \mathrm{O}_{12}$ & $-5,267,581$ & $326 \cdot 48$ & $115 \cdot 28$ \\
Hercynite & $\mathrm{FeAl}_{2} \mathrm{O}_{4}$ & $-1,952,054$ & $106 \cdot 20$ & $40 \cdot 75$ \\
Fe-cordierite & $\mathrm{Fe}_{2} \mathrm{Al}_{4} \mathrm{Si}_{3} \mathrm{O}_{12}$ & $-8,474,901$ & $377 \cdot 82$ & $232 \cdot 17$ \\
Staurolite & $\mathrm{Fe}_{2} \mathrm{Al}_{9} \mathrm{Si}_{4} \mathrm{O}_{23}(\mathrm{OH})$ & $-1,936,529$ & $449 \cdot 15$ & 223.0 \\
Chloritoid & $\mathrm{FeAl}_{2} \mathrm{SiO}_{3}(\mathrm{OH})_{2}$ & $-3,230,856$ & $124 \cdot 60$ & $69 \cdot 63$ \\
\hline
\end{tabular}

- Robie et al. (1967).

corundum were taken directly from Helgeson et al. (1978), also the heat capacities of other minerals. Molar volumes were taken from Robie et al. (1967). Enthalpies and entropies of almandine, hercynite, Fe-cordierite, staurolite and chloritoid were adjusted to make the data consistent with experimental reversals of the following equilibria:

$$
\begin{gathered}
6 \mathrm{St}+11 \mathrm{Qz}=4 \mathrm{Alm}+23 \mathrm{Ky}+3 \mathrm{H}_{2} \mathrm{O} \\
4 \text { Chloritoid }+5 \mathrm{Ky}=2 \mathrm{St}+1 \mathrm{Qz}+3 \mathrm{H}_{2} \mathrm{O} \\
3 \mathrm{FeCord}=2 \mathrm{Alm}=4 \mathrm{Sill}+5 \mathrm{Qz} \\
1 \mathrm{FeCord}=2 \mathrm{Hc}+5 \mathrm{Qz}
\end{gathered}
$$

(Ganguly, 1972; Rao \& Johannes, 1979; Holdaway \& Lee, 1977; Richardson, 1968). The data are listed in Table 7.

Ideal mixing was assumed in calculating almandine, staurolite and hercynite activities in natural phases.

(iii) Equilibria in other systems. Published calibrations of the following geothermometers and geobarometers were also used where appropriate: (a) the garnet-biotite Fe- $\mathrm{Mg}$ exchange geothermometer (Ferry \& Spear, 1978); (b) the sanidine-high albite solvus geothermometer (Stormer \& Whitney, 1977); (c) the garnet-orthopyroxene geobarometer (equilibrium 2) (Harley \& Green, 1982).

\section{Thermodynamic calculations-results}

The equilibrium constants used to calculate equilibria relevant to the sapphirine-granulites are listed in Table 8. Equilibrium curves are summarized in Fig. 16.

Despite the errors inherent in the calculations, the texturally defined sub-assemblages in the sapphirine-granulites yield distinct $P-T$ conditions for the various evolutionary stages (Fig. 16), thus supporting the textural arguments for a poly-metamorphic history. Furthermore, the sequence of calculated $P-T$ conditions define a loop. Although the exact shape of the loop is not well constrained, the systematic arrangement of $P-T$ intersections strongly suggests that the rocks have preserved a chemical record of their $P-T$ evolution and that the spread in calculated conditions is not merely the result of accumulated errors. The inferred $P-T$ history is as follows:

(1) increasing $T$ at relatively high $P$ (staurolite and pyrope stages);

(2) a maximum $T$ of $830 \pm 70^{\circ} \mathrm{C}$ reached at $10 \pm 2 \mathrm{~kb}$ (prismatic sapphirine stage);

(3) almost isothermal decompression, reaching $750 \pm 100^{\circ} \mathrm{C}$ at $5 \pm 1 \mathrm{~kb}$ (cordierite and symplectite stages);

(4) further cooling and decompression until rocks exposed. 
TA B LE 8

Equilibria and equilibrium constants used to calculate $P-T$ conditions at each stage in the metamorphic evolution of the Bresciadega samples

\begin{tabular}{|c|c|c|c|}
\hline & Equilibrium & & $\begin{array}{l}\text { Equilibrium } \\
\text { constant }\end{array}$ \\
\hline Staurolite stage & $\begin{array}{l}6 \mathrm{st}+11 \mathrm{qz}=4 \mathrm{alm}+23 \mathrm{ky}+3 \mathrm{H}_{2} \mathrm{O} \\
(T \text { maximum })\end{array}$ & (4) & 1.0 \\
\hline Pyrope stage & $\begin{array}{l}3 \mathrm{hc}+3 \mathrm{ky}=\mathrm{alm}+5 \mathrm{crm} \\
\text { musc }+\mathrm{qz}+\mathrm{H}_{2} \mathrm{O}=\mathrm{ky}+\text { melt }\end{array}$ & (7) & $\begin{array}{l}0.95 \\
1.0\end{array}$ \\
\hline \multirow[t]{2}{*}{ Prismatic sapphirine stage } & $\begin{array}{l}\mathbf{k y}=\text { sill }(P \text { minimum }) \\
\text { en }+2 \mathbf{k y}=\text { sa }+3 \mathrm{qz} \\
\text { sanidine-high albite solvus }\end{array}$ & $\begin{array}{l}(14) \\
(25)\end{array}$ & $\begin{array}{l}1.0 \\
1 \cdot 11 \\
\text { ksp: } A b_{1}: \text { plag: } A b_{1}\end{array}$ \\
\hline & $\begin{array}{l}\text { Al-en }=\text { py } \\
10 \mathrm{st}=3 \mathrm{alm}+11 \mathrm{hc}+31 \mathrm{ky}+5 \mathrm{H}_{2} \mathrm{O} \\
(T \text { maximum })\end{array}$ & $\begin{array}{l}(2) \\
(5)\end{array}$ & $\begin{array}{l}\text { Ssp: } \mathrm{AO}_{18} ; \text { plag: } \mathrm{AO}_{48} \\
X_{\mathrm{pox}}^{\mathrm{opx}}=0 \cdot 38 \\
7.75\end{array}$ \\
\hline \multirow[t]{2}{*}{ Cordierite stage } & $\begin{array}{l}\mathrm{ky}=\text { sill }(P \text { maximum }) \\
10 \mathrm{st}=3 \mathrm{alm}+11 \mathrm{hc}+31 \text { sill }+5 \mathrm{H}_{2} \mathrm{O} \\
(T \text { maximum })\end{array}$ & $\begin{array}{l}(14) \\
(5)\end{array}$ & $\begin{array}{l}1.0 \\
7.75\end{array}$ \\
\hline & $\begin{array}{l}\text { sa }+5 q z=\text { cord } \\
2 p y+2 q z=3 e n+2 \text { sill }\end{array}$ & $\begin{array}{l}(15) \\
(13)\end{array}$ & $\begin{array}{l}1.18 \text { (cores) } 1.28 \text { (rims) } \\
4.04\end{array}$ \\
\hline \multirow[t]{5}{*}{ Symplectite stage } & $4 \mathrm{en}+8$ sill $=\mathbf{s a}+3$ cord & (17) & 1.97 \\
\hline & $8 \mathrm{py}=8 \mathrm{en}+3 \mathrm{sa}+$ cord & (18) & 330 \\
\hline & $5 p y=5 e n+3$ spin + cord & $(22)$ & $14 \cdot 3$ \\
\hline & $5 \mathrm{sa}=8 \mathrm{spin}+$ cord & (21) & $\begin{array}{l}13.6 \\
X^{0 \mathrm{px}}=0.20\end{array}$ \\
\hline & Alen $=$ py & (2) & $X_{\mathrm{py}}^{\mathrm{opx}}=0 \cdot 29$ \\
\hline
\end{tabular}

These results are at variance with $P-T$ conditions calculated by Ackermand \& Seifert (1968), Wenk et al. (1974) and Hoernes \& Friedrichsen (1980) for the sapphirine-granulites. The regional significance of the $P-T$-time path is discussed below.

Two independent lines of evidence suggest that the sapphirine-granulites were relatively 'dry' during decompression:

(i) If the $P-T$ position of the phlogopite + quartz breakdown reaction (equilibrium 16) is calculated for mineral compositions appropriate to the prismatic sapphirine stage (i.e. $K_{16}=$ 2.89 ); the water activity in the fluid phase must be reduced to 0.2 in order to make the curve pass through $830^{\circ} \mathrm{C}$ at $10 \mathrm{~kb}$. The same reaction 16 operative during the cordierite stage (Opx rims separating biotite and quartz) requires even lower $\mathrm{H}_{2} \mathrm{O}$ activities.

(ii) The water content of cordierite is a function of water activity as well as $P$ and $T$ (Newton \& Wood, 1979). If it is assumed that most of the cordierite in AL20 grew from sapphirine + quartz at about $7 \mathrm{~kb}$ and $800^{\circ} \mathrm{C}$ (Fig. 16) the isohydron plot of Newton \& Wood can be used to predict the water content of cordierite under these conditions with $a_{\mathrm{H}_{2} \mathrm{O}}=1$. This value is 0.6 mole of $\mathrm{H}_{2} \mathrm{O}$ per formula unit and is much higher than the measured water content of 0.265 mole. The difference implies a low water activity in the fluid (c. 0.4 ) during cordierite growth.

\section{Anomalous results}

The equilibrium calculations give results reasonably consistent with the $\mathrm{Al}_{2} \mathrm{SiO}_{3}$ phase diagram except for the five reactions involving pyrope, sapphirine, kyanite, enstatite and quartz relevant to the prismatic sapphirine stage which were found to intersect at an anomalously low pressure. However, if the $P-T$ position of the kyanite version of equilibrium 25 is calculated by extrapolating the experimentally determined position of 25 (Chatterjee \& Schreyer, 1972) down temperature and allowing for the kyanite-sillimanite inversion and 
(a)
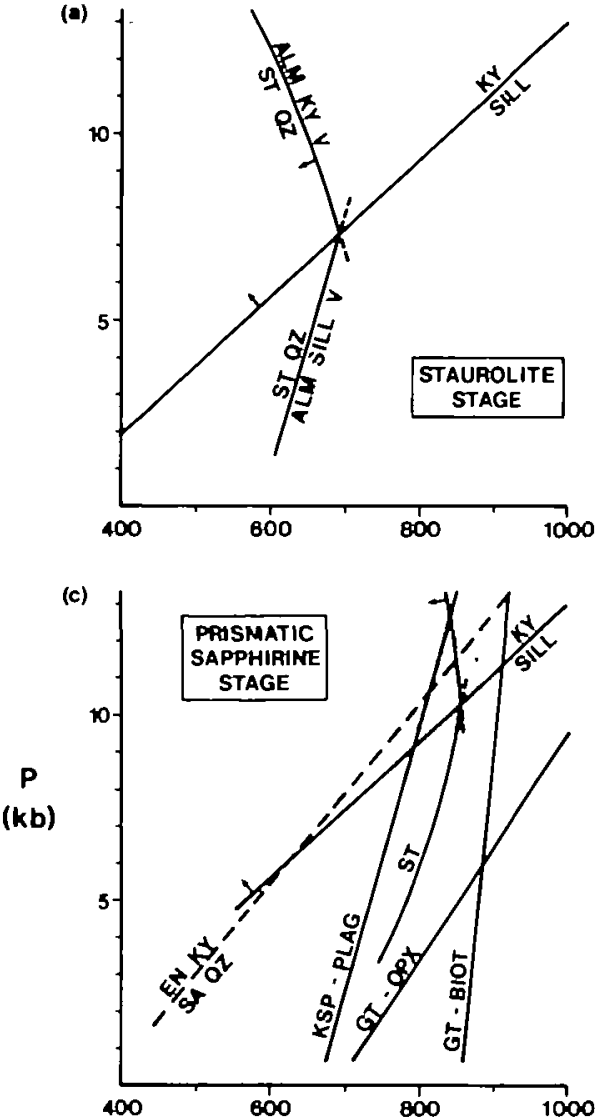

(e)

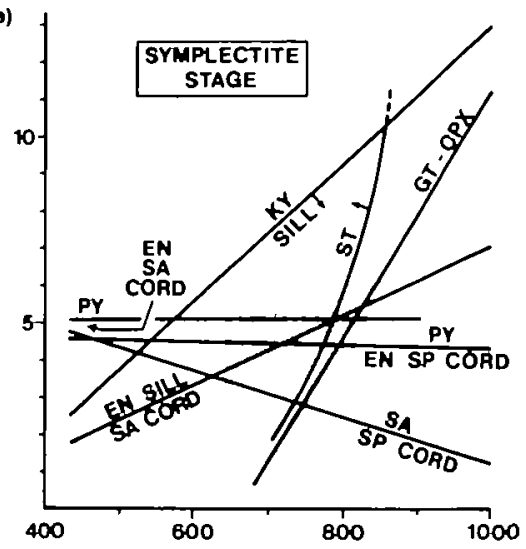

(b)

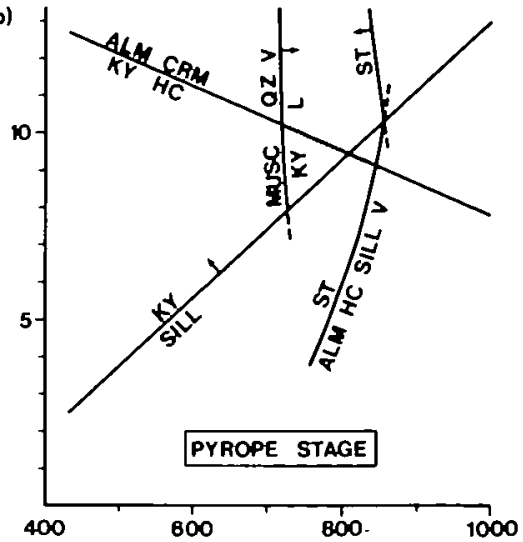

(d)

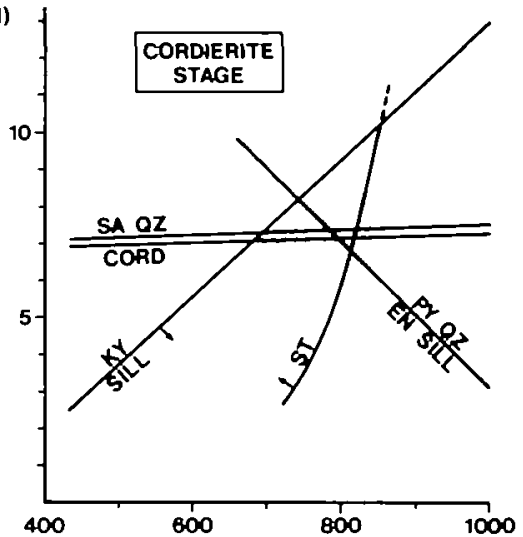

(f)

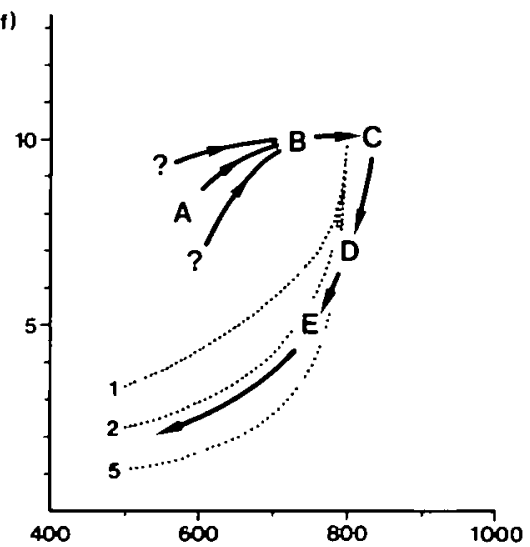

$\mathrm{T}\left({ }^{\circ} \mathrm{C}\right)$

FIG. 16. Successive metamorphic conditions and $P-T$-time trajectory of the Bresciadega sapphirine-granulites. (a) to (e): $P-T$ diagrams showing estimated conditions (shaded) at each stage in the metamorphic evolution. ( $f$ ): $P-T$-time trajectory. Dotted lines: uplift curves calculated by Albarede (1976) (uplift rates given in $\mathrm{mm} / \mathrm{yr}$ ).

impurities in coexisting prismatic sapphirine stage phases $\left(K_{25}=1 \cdot 11\right)$, the resultant curve passes through $790^{\circ} \mathrm{C}$ at $10 \mathrm{~kb}$, in good agreement with other equilibria for this stage. These difficulties again may arise from the fact that ordered sapphirine occurs in natural rocks and 
therefore experimental sapphirine equilibria are of highly uncertain value in assessing $P-T$ conditions for natural sapphirine assemblages.

The Harley \& Green (1982) garnet-orthopyroxene geobarometer gives very high temperatures $\left(>1000^{\circ} \mathrm{C}\right.$ at $\left.10 \mathrm{~kb}\right)$ when applied to coexisting garnet and high-Al orthopyroxene of the prismatic sapphirine stage. Such extreme temperatures, while more in agreement with estimates from mineralogically similar sapphirine-quartz-granulites from Antarctica (Ellis, 1980; Grew, 1980) are inconsistent with the inferred existence of kyanite and the persistence of staurolite. The geobarometer gives consistent results when applied to symplectitic orthopyroxene and retrogressive garnet extreme rim compositions.

Garnet-biotite thermometry on biotite inclusions in TS100 garnet gives anomalously low temperatures (570 to $666 \pm 50^{\circ} \mathrm{C}$ at $8 \mathrm{~kb}$ ) irrespective of position. Such temperatures clearly do not reflect conditions during prograde garnet growth as they are too low and too well clustered; it is more likely that the temperatures recorded are 'blocking temperatures' of the garnet-biotite exchange equilibrium, in which case they cannot be used to constrain conditions prevailing during a texturally defined stage in the reaction history. The low concordant oxygen isotope temperatures of Hoernes \& Friedrichsen (1980) may also reflect this type of blocking behaviour.

\section{DISCUSSION}

The inferred compositional change in the history of the sapphirine-granulites has been used to suggest that these rocks originated by in-situ parial melting. The random orientation of sapphirine-rich lenses and chemical differences between lenses and leucosome in rock Cod6 $\mathrm{A}$ support this idea. Alternatives to an in situ origin for the sapphirine rocks, such as late stage tectonic emplacement, seem highly unlikely therefore, especially since there is no evidence of shearing along sapphirine rock/leucosome contacts in the rocks Cod6A and AL19. Thus the $P-T$-time path calculated for the sapphirine rocks (Fig. $16 f$ ) is probably applicable to the entire Gruf Complex. This conclusion is consistent with the metamorphic history deduced for metapelitic gneisses and ultramafic rocks of the Gruf Complex (Bucher-Nurminen \& Droop, 1983).

The uninterrupted nature of the reaction history suggests that these features may be the product of a single metamorphic cycle. Regional geological constraints presented by Bucher-Nurminen \& Droop (1983) show that the Gruf Complex attained pressures and temperatures in excess of $4 \mathrm{~kb}$ and $700^{\circ} \mathrm{C}$ during mid-Tertiary Alpine metamorphism. Thus, although Hercynian whole rock ages have been obtained from one Gruf rock sample (Gulson, 1973) we conclude that the loop shown on Fig. $16 f$ represents the $P-T$-time path of the entire Gruf Complex during Alpine metamorphism. If forced to relegate part of the deduced metamorphic history to a pre-Alpine event, the staurolite stage would be the obvious suspect. Clearly some detailed geochronology must be done before this problem is fully resolved. This work is currently in progress.

The $P-T$-time path of Fig. $16 f$ has a 'clockwise' sense, a feature which Schuiling (1963) suggested may be normal for orogenic belts. Since his work, clockwise loops have been described from several terrains (e.g. the Eastern Alps (Holland \& Richardson, 1979); West Norway (Krogh, 1982); British Columbia (Hollister, 1982), though none as extensive as the present example. Recent theoretical calculations (England \& Richardson, 1977; Oxburgh \& England, 1980) suggest that a clockwise $P-T$-time loop is a likely consequence of concurrent thermal relaxation and erosion following tectonic crustal thickening in collisional belts. Tectonic thickening has undoubtedly taken place in the Central Alps (e.g. Trümpy, 1980). In detail, however, the estimated $P-T$-time loop does not correspond to the theoretically derived 
trajectories in that the nearly isothermal decompression path is very steep and a stage of simultaneous $T$ increase and $P$ decrease is absent. The discrepancy could be explained if, in the vicinity of the Gruf Complex, (a) a close approach to a thermal 'steady state' existed prior to erosion, and (b) initial uplift was extremely rapid. In a collisional orogen the achievement of a thermal 'steady state' is unlikely, but might be closely approached if there is either (i) a very long time interval between rapid tectonic thickening and the onset of erosion, or (ii) an extended period of simultaneous heating and slow tectonic thickening prior to erosion. The slope of the prograde trajectory in $P-T$ space should enable one to choose between these alternatives, but the present data are not precise enough to resolve this.

Existing geochronological data can be used in conjunction with the observed $P-T$-time path to constrain possible uplift rates of the Gruf Complex. In the Central Alps the thermal peak of 'Lepontine' metamorphism occurred 38-35 m.y. ago (Jäger, 1973). If these figures also apply to the Gruf Complex, $38 \mathrm{~m} . \mathrm{y}$. is the earliest date at which the sapphirine-granulites could have begun decompression from $10 \mathrm{~kb}$ (c. $35 \mathrm{~km}$ depth). The Bergell Granite was intruded 30 m.y. ago (Gulson \& Krogh, 1973). Thermally metamorphosed country rocks at the eastern margin of the intrusion crystallized at 2-3 kb (Bucher-Nurminen, 1977). Since the difference in the structural depth between the eastern margin and the western (lower) contact can be no more than 6 to $7 \mathrm{~km}$, the Gruf rocks in Val Codera were at 4 to $5 \mathrm{~kb} 30 \mathrm{~m}$.y. ago and therefore underwent a pressure drop of at least $5 \mathrm{~kb}$ in $8 \mathrm{~m} . \mathrm{y}$. This indicates that the average uplift rate of the Gruf Complex was at least $2.2 \mathrm{~mm} / \mathrm{yr}$ in the period $38-30 \mathrm{~m}$.y. ago.

In theory it should also be possible to calculate the initial uplift of the Gruf Complex from the slope of the decompressive part of the $P$ - $T$-time path, especially if an initial thermal 'steady state' can be assumed, and hence to date the onset of erosion. Albarede (1976) has calculated model $P-T$-time paths for deep crustal rocks (initially at $800^{\circ} \mathrm{C}, 10 \mathrm{~kb}$ ) exhumed at different rates. The calculated curve that most closely matches the slope of the deduced trajectory (Fig. 16f) is the one for an erosion rate of $2 \mathrm{~mm}$ per year. This would be at best an order of magnitude estimate for the Gruf Complex because (a) our trajectory is not precisely located, and (b) Albarede's model may not be applicable. Nevertheless it agrees well with the figure obtained above and implies that Jäger's date of $38 \mathrm{~m} . \mathrm{y}$. is valid for the regional metamorphic peak in the Bergell region.

This high initial uplift rate corroborates the data of Schmutz (1976) who reported a highly compressed sequence of $\mathrm{E}-\mathrm{W}$ trending isograds along the northern contact of the Gruf Complex (Fig. 1). This isograd pattern in the Chiavenna ophiolite sequence may be explained by large horizontal thermal gradients set up by the rapid uplift and juxtaposition of hot Gruf rocks against comparatively cool Chiavenna ultramafics and Tambo Gneisses to the north.

For the last 23 m.y., uplift rates in the Bergell area have been lower and decreasing $(0.7$ $\mathrm{mm} / \mathrm{yr}$ down to $0.2 \mathrm{~mm} / \mathrm{yr}$ ) (Wagner et al., 1977, 1979). Viewed together with the deduced high initial uplift rate $(>2 \mathrm{~mm} / \mathrm{yr}$ ), these data suggest that the Bergell region has experienced a continuously decreasing uplift rate since the Oligocene.

\section{ACKNOWLEDGEMENTS}

We are very grateful to $E$. Wenk and $S$. Hoernes for donating material from the crucial samples Cod6A and TS100, respectively, and to P. J. Treloar for help with the microprobe analyses. Our thanks go to G. A. Chinner, T. J. B. Holland, D. J. Waters, P. R. A. Wells and members of the Geology Departments at Oxford and Basel for valuable discussion and criticism. We also thank an anonymous reviewer for painstakingly dissecting an earlier version of this paper. 


\section{REFERENCES}

Ackermand, D., \& Seifert, F., 1969. Druck und Temperaturbedingungen bei der Bildung der sapphirinführenden Gesteine von Val Codera. Fortschr. Miner. 47, 1 (Abstract).

- \& Schreyer, W., 1975. Instability of sapphirine at high pressures. Contr. Miner. Petrol. 60, 79-92.

Albarede, F., 1976. Thermal models of post-tectonic decompression as exemplified by the Haut-Allier granulites (Massif Central, France). Bull. Soc. geol. France, 18, 1023-32.

Barker, F., 1964. Sapphirine-bearing rock, Val Codera, Italy. Am. Miner. 49, 146-52.

Bucher-Nurminen, K., 1977. Die Beziehung zwischen Deformation, Metamorphose und Magmatismus im Gebeit der Bergeller Alpen. Schweiz. miner. petrogr. Mitt. 57, 413-34.

\& Droop, G. T. R., 1983. The metamorphic evolution of garnet-cordierite-sillimanite-gneisses of the Gruf Complex, Eastern Pennine Alps. Contr. Miner. Petrol. 84, 215-27.

Caporuscio, F. A., \& Morse, S. A., 1978. Occurrence of sapphirine plus quartz at Peckskill, New York. Am. J. Sci. 278, $1334-42$.

Charlu, T. V., Newton, R. C., \& Kleppa, O. J., 1975. Enthalpies of formation at $970{ }^{\circ} \mathrm{K}$ of compounds in the system $\mathrm{MgO}-\mathrm{Al}_{2} \mathrm{O}_{3}-\mathrm{SiO}_{2}$ from high temperature solution calorimetry. Geochim. cosmochim. Acta, 39, $1487-97$.

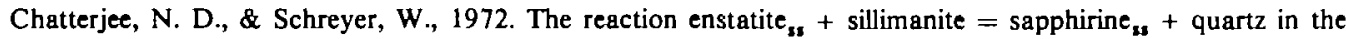
system $\mathrm{MgO}-\mathrm{Al}_{2} \mathrm{O}_{3}-\mathrm{SiO}_{2}$. Contr. Mineral. Petrol. 36, 49-62.

Chinner, G. A., \& Sweatman, T. R., 1968. A former association of enstatite and kyanite. Miner. Mag. 36, $1052-60$.

Cornelius, H. P., 1916. Ein alpines Vorkommen von Sapphirine. Cent. Mineral. 265-9.

\& Dittler, E., 1929. Zur Kenntnis des Sapphirinvorkommens von Alpe Bresciadega in Val Codera (Italien, Prov. Sondrio). Neues Jb. Miner. Abh. 59, 27-64.

Dallwitz, W. B., 1968. Coexisting sapphirine and quartz in granulite from Enderby Land, Antarctica. Nature, 219, 476-7.

De Bethune, P., Laduron, D., \& Boquet, J., 1975. Diffusion processes in resorbed garnets. Contr. Mineral. Petrol. s0, 197-204.

Deer, W. A., Howie, R. A., \& Zussman, J., 1978. Rock-Forming Minerals. Vol. 2A. Single-Chain Silicates. London: Longman.

Dunham, A. C., \& Wilkinson, F. C. F., 1978. Accuracy, precision and detection limits of energy-dispersive electron-microprobe analyses of silicates. $X$-ray Spectrom. 7, 50-6.

Ellis, D. J., 1980. Osmulite-sapphirine-quartz granulites from Enderby Land, Antarctica: $P-T$ conditions of metamorphism, implications for garnet-cordierite equilibria and the evolution of the deep crust. Contr. Miner. Petrol. 74, 201-10.

- Sheraton, J. W., England, R. N., \& Dallwitz, W. B., 1980. Osumilite-sapphirine-quartz granulites from Enderby Land, Antarctica-mineral assemblages and reactions. Ibid. 72, 123-43.

England, P. C., \& Richardson, S. W,m 1977. The influence of erosion upon the mineral facies of rocks from different metamorphic environments. J. geol. Soc. London, 134, 201-13.

Ferry, J. M., \& Spear, F. S., 1978. Experimental calibration of the partition of Fe and $\mathrm{Mg}$ between biotite and garnet. Contr. Miner. Petrol. 66, 113-7.

Ganguly, J., 1972. Staurolite stability and related parageneses: theory, experiments and applications. J. Petrology, $13,335-65$.

Grant, J. A., \& Weiblen, P. W., 1971. Retrograde zoning in garnet near the second sillimanite isograd. Am. J. Sct. 270, 281-96.

Grew, E. S., 1980. Sapphirine + quartz association from Archaean rocks in Enderby Land, Antarctica. Am. Miner. 65, 821-36.

1982a. Sapphirine, kornerupine and sillimanite + orthopyroxene in the charnockitic region of South India. $J$. geol. Soc. India, 23, 469-505.

- 1982b. Osumilite in the sapphirine-quartz terrane of Enderby Land, Antarctica: implications for osumilite petrogenesis in the granulite facies. A m. Miner. 67, 762-87.

Griffen, D. T., Gosney, T. C., \& Phillips, W. R., 1982. The chemical formula of natural staurolite. Ibid. 67, $292-7$.

Gulson, B. L., 1973. Age relations in the Bergell region of the southeast Swiss Alps: with some geochemical comparisons. Eclog. geol. Helv. 66, 293-323.

— \& Krogh, T. E., 1973. Old lead components in a young Alpine granitic massif. Contr. Miner. Petrol. 40, 239-57.

Harley, S. L., \& Green, D. H., 1982. Garnet-orthopyroxene barometry for granulites and peridotites. Nature, 300, 697-701.

Harris, N. B. W., \& Holland, T. J. B., 1984. The significance of cordierite-hypersthene assemblages from the Beitbridge region of the Central Limpopo Belt; evidence for rapid decompression in the Archaean? Contr. Miner. Petrol. (in press).

Helgeson, H. C., Delaney, J. M., Hesbitt, H. W., \& Bird, D. K., 1978. Summary and critique of the thermodynamic properties of rock-forming minerals. Am. J. Sci. 278A, 1-229.

Hensen, B. J., 1972. Phase relations involving pyrope, enstatite ${ }_{s s}$ and sapphirine ss $_{s}$ in the system $\mathrm{MgO}-$ $\mathrm{Al}_{2} \mathrm{O}_{3}-\mathrm{SiO}_{2}$. Yb. Carnegie Insin. Wash. 71, 421-7. 
\& Essene, E. J., 1971. Stability of pyrope-quartz in the system $\mathrm{MgO}-\mathrm{Al}_{2} \mathrm{O}_{3}-\mathrm{SiO}_{2}$. Contr. Minerl Petrol. 30 , 72-83.

Higgins, J. B., Ribbe, P. H., \& Herd, R. K., 1979. Sapphirine I: Crystal chemical contributions. Ibid. 68, 349-56.

Hoernes, S., \& Friedrichsen, H., 1980. Oxygen and hydrogen isotopic composition of Alpine and pre-Alpine minerals in the Swiss Central Alps. Contr. Miner. Petrol. 72, 19-32.

Holdaway, M. J., \& Lee, Sang Man, 1977. Fe-Mg cordierite stability in high-grade pelitic rocks based on experimental, theoretical and natural observations. Ibid. 63, 175-98.

Holland, T. J. B., \& Richardson, S. W., 1979. Amphibole zonation in metabasites as a guide to evolution of metamorphic conditions. Jbld. 70, 143-8.

Hollister, L. S., 1982. Metamorphic evidence for rapid $(2 \mathrm{~mm} / \mathrm{yr}$ ) uplift of a portion of the Central Gneiss Complex, Coast Mountains, BC. Can. Mineralogist, 20, 319-32.

Jäger, E., 1973. Die alpine Orogenese in Lichte der radiometrischen Alterbestimmungen. Eclog. geol. Helv. 66, $11-21$.

Karsakov, L. P.; Shuldiner, V. I., \& Lennikov, A. M. 1975. Granulite province of the eastern part of the Stanovoy Fold Province and the Chogar facies of depth. Izvestiya Akad. Nauk SSSR, Ser. Geol. 1975(5), 47-61. (in Russian).

Kiseleva, I. A.; 1976. Thermodynamic parameters of natural ordered sapphirine and synthetic disordered specimens. Geochem. Internat. 13, 113-22.

Kleppa, O. J., \& New ton, R. C., 1975. The role of solution calorimetry in the study of mineral equilibria. Fortschr. Miner. 52, 3-20.

Krogh, E. J., 1982. Metamorphic evolution of Norwegian country-rock eclogites as deduced from mineral inclusions and compositional zoning in garnets. Lithos, 15, 305-21.

Lal, R. K., Ackermand, D., Seifert, F., \& Haldar, S. K., 1978. Chemographic relationships in sapphirine-bearing rocks from Sonapahar, Assam, India. Contr. Miner. Petrol. 67, 169-87.

Lensch, G., 1971. Das Vorkommen von Sapphirin im Peridotitkörper von Finero (Zone von Ivrea, Italienische Westalpen). Ibid. 31, 145-53.

Leyreloup, A., Lasnier, B., \& Marchland, J., 1975. Retrograde corona-forming reactions in high pressure granulite facies rocks. Petrologie, 1, 43-55.

MacRae, N. D., \& Nesbitt, H. W., 1980. Partial melting of common metasedimentary rocks: a mass balance approach. Contr. Miner. Petrol. 75, 21-6.

McKie, D., 1959. Yoderite, a new hydrous magnesium iron aluminosilicate from Mautia Hill, Tanzania. Miner. Mag. 32, 282-307.

Meng, Leong Khee, \& Moore, J. M., 1972. Sapphirine-bearing rocks near Wilson Lake, Labrador. Can. Mineralogist, $11,777-90$.

Morse, S. A., \& Talley, J. H., 1971. Sapphirine reactions in deep-seated granulites near Wilson Lake, Central Labrador, Canada. Earth planet. Sci. Lett. 10, 325-8.

Moticska, P., 1970. Petrographie und Strukturanalyse des Westlichen Bergeller Massifs und seines Rahmens. Schweiz. miner. petrogr. Mitt. 50, 355-443.

Muthuswami, T. N., 1949. Sapphirine (Madura). Proc. Indian Acad. Sci., Section A, 30, 295-301.

Newton, R. C., 1972. An experimental determination of the high pressure stability limits of magnesian cordierite under wet and dry conditions. J. Geol. 80, 398-420.

__ \& Wood, B. J., 1979. Thermodynamics of water in cordierite and some petrologic consequences of cordierite as a hydrous system. Contr. Miner. Petrol. 68, 391-405.

Nixon, P. H., Reedman, H. J., \& Burns, L. K., 1973. Sapphirine-bearing granulite from Labwor, Uganda. Miner. Mag. 39, 420-8.

Oxburgh, E. R., \& England, P. C., 1980. Heat flow and the metamorphic evolution of the Eastern Alps. Eclog. geol. Helv. 73, 379-98.

Powell, R., 1983. Fluids and melting under upper amphibolite facies conditions. J. geol. Soc. London, 140, 629-34.

Rao, B., \& Johannes, W., 1979. Further data on the stability of staurolite + quartz and related assemblages. Neues Jb. Miner. Mh. 437-47.

Ribbe, P. H., 1982. Staurolite. In: Ribbe, P. H. (ed.) Orthosilicates. Reviews in Mineralogy. 5, $171-87$.

Richardson, S. W., 1968. Staurolite stability in a part of the system Fe-Al-Si-O-H. J. Petrology, 9, 467-88.

Robie, R. A., Bethke, P. M., \& Beardsley, K. M., 1967. Selected X-ray crystallographic data, molar volumes and densities of minerals and related substances. Bull. U.S. geol. Surv. 1248.

Schmutz, H.-V., 1976. Der Mafitit-Ultramafitit-Komplex zwischen Chiavenna und Val Bondasca. Beitr. geol. Karte Schweiz, 149.

Schreyer, W., 1970. Metamorphose pelitischer Gesteine im Modellsystem $\mathrm{MgO}_{\mathrm{g}} \mathrm{Al}_{2} \mathrm{O}_{3}-\mathrm{SiO}_{2}-\mathrm{H}_{2} \mathrm{O}$. Fortschr. Miner. 47, 124-65.

__ \& Abraham, K., 1978. Symplectitic cordierite-orthopyroxene-garnet assemblages as products of contact metamorphism of pre-existing basement granulites in the Vredefort structure, South Africa and their relation to pseudotachylite. Contr. Miner. Petrol. 68. 53-62.

Schuiling, R. D., 1963. Some remarks concerning the scarcity of retrograde vs. progressive metamorphism. Geol. Mijnbouw, 177-9. 
Statham, P. J., 1976. A comparative study of techniques for quantitative analysis of the X-ray spectra obtained with a $\mathrm{Si}(\mathrm{Li})$ detector. $X$-ray Spectrom. 9, 16-28.

Stormer, J. C., \& Whitney, J. A., 1977. Two-feldspar geothermometry in granulite facies metamorphic rocks. Sapphirine granulites from Brazil. Contr. Miner. Petrol. 65, 123-33.

Storre, B., $\approx$ Karotke, E., 1972. Experimental data on melting reactions of muscovite + quartz in the system $\mathrm{K}_{2} \mathrm{O}-\mathrm{Al}_{2} \mathrm{O}_{3}-\mathrm{SiO}_{2}-\mathrm{H}_{2} \mathrm{O}$ to $20 \mathrm{~kb}$ water pressure. Contr. Miner. Petrol. 36, 343-5.

Sweatman, T. R., \& Long, J. V. P., 1969. Quantitative electron-probe microanalysis of rock-forming minerals. J. Petrology, 10, 322-79.

Thompson, A. B., 1976. Mineral reactions in pelitic rocks: I. Prediction of $P-T-X_{(\mathrm{Fe} \text { es) }}$ phase relations. Am. J. Sci. 276, 401-24.

- Tracy, R. J., Lyttle, P. T., \& Thompson, J. B., 1977. Prograde reaction histories deduced from compositional zonation and mineral inclusions in garnet from the Gassetts Schist, Vermont. Am. J. Sci. 277, $1152-67$.

Trümpy, R., 1980. Geology of Switzerland: a gulde-book. Part A. An Outline of the Geology of Switzerland. Basel: Wepf.

Vielzeuf, D., 1980. Orthopyroxene and cordierite secondary assemblages in the granulitic paragneisses from Lherz and Saleix (French Pyrences). Bull. Mineral. 103, 66-78.

1983. The spinel and quartz association in high-grade xenoliths from Tallante (S. E. Spain) and their potential use in geothermometry and barometry. Contr. Miner. Petrol. 82, 301-11.

Wagner, G. A., Miller, D. S., \& Jäger, E., 1979. Fission-track ages on apatite of Bergell rocks from Central Alps and Bergell boulders in Oligocene sediments. Earth planet. Sci. Lett. 45, 355-60.

- Reimer, G. M., \& Jäger, E., 1977. Cooling ages derived by apatite fission-track, mica $\mathrm{Rb}-\mathrm{Sr}$ and $\mathrm{K}-\mathrm{Ar}$ dating: the uplift and cooling history of the Central Alps. Mem. Inst. Geol. Miner. Univ. Padova, 30.

Wenk, H.-R., 1973. The structure of the Bergell Alps. Eclog. geol. Helv. 66, 255-91.

- Wenk, E., \& Wallace, J. H., 1974. Metamorphic mineral assemblages in pelitic rocks of the Bergell Alps. Schweiz. miner. petrogr. Mitt. 54, 507-54.

Wilson, A. F., 1971. Some geochemical aspects of the sapphirine-bearing pyroxenites and related highly metamorphosed rocks from the Archaean ultramafic belt of South Quairading, Western Australia. Spec. Publ. geol. Soc. Australla, 3, 401-11.

Woodsworth, G. J., 1977. Homogenisation of zoned garnets from pelitic schists. Can. Mineralogist, 15, $230-42$.

\section{APPENDIX}

\section{Abbreviations}

$\begin{array}{llll}\mathrm{Ab} & \text { Albite } & \mathrm{Ilm} & \text { Ilmenite } \\ \mathrm{Alm} & \text { Almandine } & \mathrm{Ksp} & \text { K-feldspar } \\ \mathrm{An} & \text { Anorthite } & \mathrm{Ky} & \text { Kyanite } \\ \text { Anth } & \text { Anthophyllite } & \mathrm{MgTs} & \text { Mg-Tschermak's Pyroxene } \\ \mathrm{Ap} & \text { Apatite } & \mathrm{Mt} & \text { Magnetite } \\ \mathrm{Biot} & \text { Biotite } & \mathrm{Musc} & \text { Muscovite } \\ \text { Cord } & \text { Cordierite } & \mathrm{Opx} & \text { Orthopyroxene } \\ \mathrm{Crm} & \text { Corundum } & \mathrm{Or} & \text { Orthoclase } \\ \text { En } & \text { Enstatite } & \mathrm{Plag} & \text { Plagioclase } \\ \text { FeCord } & \text { Ferro-Cordierite } & \mathrm{Py} & \text { Pyrope } \\ \text { Fe }{ }^{2+} \mathrm{Ts} & \text { Ferro-Tschermak's Pyroxene } & \mathrm{Qz} & \text { Quartz } \\ \text { Fs } & \text { Ferrosilite } & \mathrm{Rut} & \text { Rutile } \\ \text { Gahn } & \text { Gahnite } & \mathrm{Sa} & \text { Sapphirine } \\ \text { Geik } & \text { Geikilite } & \mathrm{Sill} & \text { Sillimanite } \\ \mathrm{Gt} & \text { Garnet } & \mathrm{Sp} & \text { Spinel } \\ \mathrm{Hc} & \text { Hercynite } & \mathrm{St} & \text { Staurolite } \\ \mathrm{Hem} & \text { Hematite } & & \end{array}$

